\title{
Curses or Cures: A Review of the Numerous Benefits Versus the Biosecurity Concerns of Conotoxin Research
}

\author{
Walden E. Bjørn-Yoshimoto ${ }^{1}$ (D) Iris Bea L. Ramiro ${ }^{1}$ (D), Mark Yandell ${ }^{2,3}$, J. Michael McIntosh ${ }^{4,5,6}$, \\ Baldomero M. Olivera ${ }^{4}$, Lars Ellgaard ${ }^{7}$ (D) and Helena Safavi-Hemami ${ }^{1,4,8, *(D)}$ \\ 1 Department of Biomedical Sciences, University of Copenhagen, 2200 Copenhagen N, Denmark; \\ walden@sund.ku.dk (W.E.B.-Y.); iris.ramiro@sund.ku.dk (I.B.L.R.) \\ 2 Eccles Institute of Human Genetics, University of Utah, Salt Lake City, UT 84112, USA; \\ myandell@genetics.utah.edu \\ 3 Utah Center for Genetic Discovery, University of Utah, Salt Lake City, UT 84112, USA \\ 4 School of Biological Sciences, University of Utah, Salt Lake City, UT 84112, USA; \\ mcintosh.mike@gmail.com (J.M.M.); olivera@biology.utah.edu (B.M.O.) \\ 5 George E. Whalen Veterans Affairs Medical Center, Salt Lake City, UT 84148, USA \\ 6 Department of Psychiatry, University of Utah, Salt Lake City, UT 84108, USA \\ 7 Department of Biology, Linderstrøm-Lang Centre for Protein Science, University of Copenhagen, \\ 2200 Copenhagen N, Denmark; lellgaard@bio.ku.dk \\ 8 Department of Biochemistry, University of Utah, Salt Lake City, UT 84112, USA \\ * Correspondence: safavihelena@sund.ku.dk
}

Received: 30 June 2020; Accepted: 19 July 2020; Published: 22 July 2020

\begin{abstract}
Conotoxins form a diverse group of peptide toxins found in the venom of predatory marine cone snails. Decades of conotoxin research have provided numerous measurable scientific and societal benefits. These include their use as a drug, diagnostic agent, drug leads, and research tools in neuroscience, pharmacology, biochemistry, structural biology, and molecular evolution. Human envenomations by cone snails are rare but can be fatal. Death by envenomation is likely caused by a small set of toxins that induce muscle paralysis of the diaphragm, resulting in respiratory arrest. The potency of these toxins led to concerns regarding the potential development and use of conotoxins as biological weapons. To address this, various regulatory measures have been introduced that limit the use and access of conotoxins within the research community. Some of these regulations apply to all of the $\approx 200,000$ conotoxins predicted to exist in nature of which less than $0.05 \%$ are estimated to have any significant toxicity in humans. In this review we provide an overview of the many benefits of conotoxin research, and contrast these to the perceived biosecurity concerns of conotoxins and research thereof.
\end{abstract}

Keywords: conotoxin; conopeptide; cone snail; venom; envenomations; fatalities; drugs; biosecurity; biomedicine

\section{Introduction}

This article is divided into four sections. In the introductory section we provide an overview of the definition and classification of conotoxins, their chemical and pharmacological diversity, and a brief history of the methodologies used for conotoxin discovery. In the second section we highlight measurable scientific and societal benefits of conotoxin research with a view toward the future. The third section addresses biosecurity concerns and past and current regulations of conotoxins. In this section we discuss fatalities resulting from cone snail envenomations, toxicity data of selected 
conotoxins, the potential misuse of conotoxins as biological weapons, and their fictional use as murder weapons in the literature and popular media. In the concluding remarks, we assess the effectiveness and justification of regulations and suggest revisions of some current regulatory measures.

\subsection{Conotoxin Definition, Classification, and Discovery}

Venomous cone snails comprise a large and diverse lineage of marine gastropods within the family of Conidae (superfamily Conoidea) [1-4]. Based on molecular phylogenetic data, cone snails can be grouped into $\approx 57$ distinct clades (or subgenera) [5], all of which use venom for prey capture (examples shown in Figure 1).

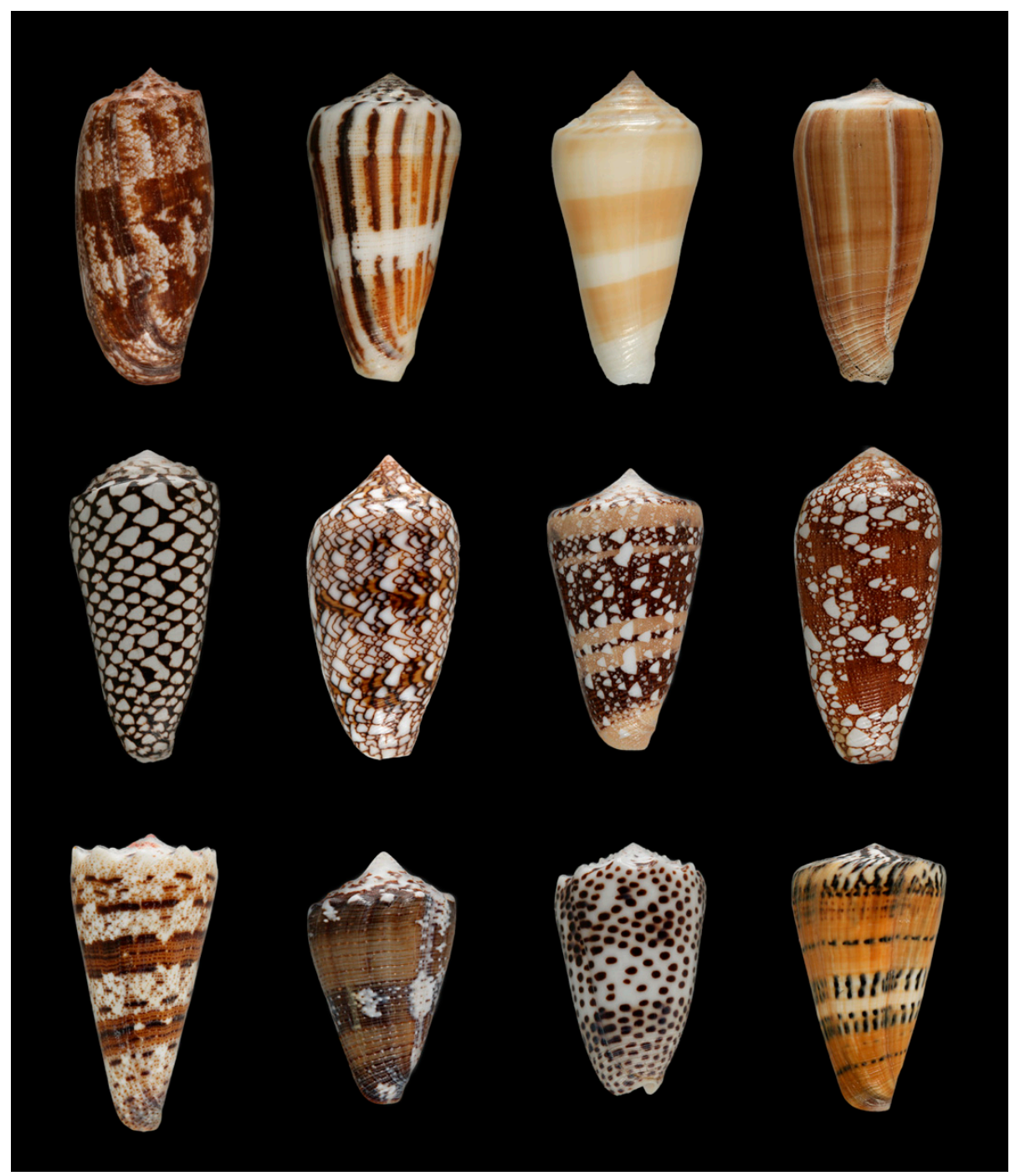

Figure 1. Shells of selected cone snail species from nine subgenera (for subgenus classification see [5]). Top row: fish-hunting cone snails (from left to right: Conus geographus (Gastridium), Conus magus and Conus consors (Pionoconus), Conus purpurascens (Chelyconus)), middle row: snail-hunting cone snails (Conus marmoreus (Conus), Conus textile and Conus ammiralis (Cylinder), Conus omaria (Darioconus)), bottom row: worm-hunting species (Conus imperialis and Conus regius (Stephanoconus), Conus pulicarius (Puncticulis), Conus mustelinus (Rhizoconus)). Shells not to scale.

In the most basic sense, a conotoxin is a toxin identified from any of the $\approx 1000$ living cone snails. The majority of conotoxins are gene-derived peptides that are synthesized at the ribosome and further processed in the endoplasmic reticulum (ER) and Golgi apparatus of the secretory cells 
of the venom gland. Small molecules of non-peptidic nature have also been isolated from cone snail venom. These have traditionally not been defined as "conotoxins", but instead named according to their characteristic chemical structures (for example [6,7]). Cone snail small molecules have not been subject to regulation and will therefore not be further discussed in this review.

The majority of conotoxins identified to date contain disulfide bonds that are formed between cysteine residues to confer structural stability and resistance against proteolytic degradation [8]. However, not all conotoxins contain cysteines and it has been suggested that conotoxins should be classified into those that are cysteine-rich (i.e., containing more than one disulfide bond) and those that are cysteine-poor (i.e., containing only one or no disulfide bonds). The term "conopeptide" was suggested to describe the latter group. However, this distinction has not received traction in the field and both terms conotoxin and conopeptide are now being used interchangeably [9].

Three biochemical and pharmacological features have been used to broadly classify conotoxins into distinct groups: their pharmacological target and activity (typically designated by a Greek letter), their cysteine framework (designated by Roman numerals) and their gene superfamily (designated by Latin letters). For example, conotoxins $\alpha \mathbf{A}-\mathrm{GI}$ and $\alpha \mathbf{M}-\mathbf{M I I I J}$ both target the nicotinic acetylcholine receptor (nAChR) as represented by the Greek letter $\alpha$ but their genes and cysteine frameworks do not share any homology; one belongs to the A gene superfamily and has a type I cysteine framework while the other belongs to the $\mathbf{M}$ gene superfamily and has a type III cysteine framework. To date, more than 10 distinct pharmacological classes, 50 gene superfamilies, and 28 cysteine frameworks have been described [10], and more are likely to be discovered in the future.

The five best studied pharmacological classes of conotoxins all target ion channels expressed in the nervous and locomotor systems: $\alpha$ (inhibitors of nAChR), $\omega$ (inhibitors of voltage-gated calcium channels, VGCC), $\kappa$ (inhibitors of voltage-gated potassium channels, VGKC), $\boldsymbol{\mu}$ (inhibitors of voltage-gated sodium channels, VGSC), and $\delta$ (delayers of activation of voltage-gated sodium channels, VGSC) (Table 1). Not all pharmacological classes of conotoxins have a Greek letter designation. Instead, some have been named according to their sequence homology or similarity to other peptides (e.g., conopressins share sequence homology to vasopressin-oxytocin and coninsulins to insulin) or according to their phenotypic effect in mice (e.g., Conantokins, toxins that induce a sleep-like state in mice, were named after the Filipino word for sleep, "antok") (Table 1).

Table 1. Pharmacological families of conotoxins (in alphabetical order, modified from [10]).

\begin{tabular}{|c|c|c|c|c|}
\hline $\begin{array}{l}\text { Pharmacological } \\
\text { Family }\end{array}$ & Molecular Target & Molecular Mechanism & $\begin{array}{l}\text { Reference } \\
\text { Conotoxin }\end{array}$ & Reference \\
\hline$\alpha$ (alpha) & $\begin{array}{l}\text { Nicotinic acetylcholine receptors } \\
\text { (nAChR) }\end{array}$ & Receptor antagonists & GI & [11] \\
\hline$\gamma$ (gamma) & $\begin{array}{c}\text { Neuronal pacemaker cation } \\
\text { channels }\end{array}$ & $\begin{array}{c}\text { Channel activator, } \\
\text { potentially indirect effect }\end{array}$ & PnVIIA & [12] \\
\hline$\delta$ (delta) & Voltage-gated Na channel & Delay channel inactivation & PVIA & [13] \\
\hline l (iota) & Voltage-gated Na channels & Channel activators & RXIA & [14] \\
\hline к (kappa) & Voltage-gated K channels & Channel blockers & PVIIA & [15] \\
\hline$\mu(\mathrm{mu})$ & Voltage-gated Na channels & Channel blockers & GIIIA & [16] \\
\hline$\varrho($ rho $)$ & $\alpha 1$ adrenoreceptors & Allosteric inhibitor & TIA & [17] \\
\hline$\sigma($ sigma $)$ & $\begin{array}{c}\text { 5-hydroxytryptamine } 3 \text { receptor } \\
\text { (HTR3A) }\end{array}$ & Receptor antagonist & GVIIIA & [18] \\
\hline$\tau($ tao $)$ & Somatostatin receptor (SSTR) & Receptor antagonist & CnVA & [19] \\
\hline$x($ chi) & Norepinephrine Transporter & Inhibitor & MrIA & [17] \\
\hline$\omega$ (omega) & Voltage-gated Ca channels & Channel blockers & GVIA & [20] \\
\hline$\Phi(\mathrm{phi})$ & Promotes cell proliferation & Not determined & MiXXVIIA & [21] \\
\hline \multicolumn{5}{|c|}{ Examples of pharmacological families without Greek letter designation } \\
\hline Conantokins & $\begin{array}{l}\text { N-methyl-D-aspartate receptor } \\
\text { (NMDAR) }\end{array}$ & Receptor antagonists & Conantokin-G & [22] \\
\hline Coninsulins & Insulin receptor & \multirow{2}{*}{$\begin{array}{l}\text { Receptor agonists } \\
\text { Receptor agonists and } \\
\text { antagonists }\end{array}$} & Con-Insulin G1 & [23] \\
\hline Conopressins & Vasopressin receptor & & Lys-Conopressin-G & [24] \\
\hline
\end{tabular}




\subsection{Conotoxin Discovery}

In the early days of conotoxin discovery, dating back to the 1960s, conotoxins were directly isolated from dissected venom, usually by bioassay-directed fractionation and sequencing (for example [11, 25-27]). Thus, discovery was focused on the biological activity of a newly identified toxin, and as such, the toxin's pharmacological activity and classification was usually determined. A common assay used to identify new toxins was by intracranial (IC; into the brain) or intraperitoneal (IP; into the abdominal cavity) injection of fractionated venom compounds into mice followed by observational recording [11,22,25-30]. Sequencing of active components required several rounds of purification from the complex venom mixture. As the conotoxins that elicited the most severe phenotypes when injected in mice could be more easily traced during purification, most conotoxins identified early on were those that were potently active in vertebrates and elicited severe effects such as seizures, shaking, paralysis, respiratory distress, or death [11,22,25-30]. Conotoxins that did not elicit a strong physiological response were not pursued or not reported (for example, see [31]). This may have resulted in the perception that most conotoxins have severe toxicity in vertebrates. Additionally, early studies predominantly focused on the venom of fish-hunting (piscovorous) cone snails. However, fish hunters constitute fewer than $20 \%$ of the total species diversity of cone snails [32]. The vast majority of cone snails prey on worms (vermivorous), and a small fraction of species prey on other mollusks (molluscivorous). Conotoxins isolated from piscovorous species are more likely to show toxicity in vertebrates than those isolated from vermivorous and molluscivorous species. Indeed, as conotoxin research expanded to the venoms of worm- and snail-hunting species and to more diverse sets of toxins from fish-hunters (e.g., $\alpha$-conotoxins that target neuronal nAChRs, coninsulins, conopressins), the number of conotoxins with no or very low phenotypic activity in vertebrates steadily increased [10,33]. The vast majority of conotoxins isolated from venom to date have little to no toxicity in vertebrates.

The advent of genome sequencing in the 2000s dramatically changed how conotoxins could be identified; toxin sequences could now be readily deduced from genomic DNA or mRNA without the need to physically isolate toxins from venom. This led to a dramatic increase in the rate of conotoxin discovery; today more than 20,000 conotoxin sequences have been identified with thousands more anticipated to be sequenced in the coming years. The vast majority of these conotoxins have never been directly isolated from venom and their pharmacological activity remains unknown. For toxin sequences that share significant homology with toxins of known pharmacologies, activity can sometimes be predicted, but potencies and subtype selectivity profiles are difficult to predict. Activities of conotoxin sequences that do not share significant homology with known toxins are impossible to predict and, one may argue, these should not even be called conotoxins until a biological activity or presence in venom has been verified. To address this issue we previously proposed the usage of "conotoxin candidate" or "putative conotoxin" until future evidence can verify that a newly identified sequence indeed encodes a biologically active toxin (and is not merely predicted to do so) [34]. However, currently, there is no consensus in the field about how to best define newly identified conotoxin sequences.

While the difficulty of defining and classifying toxin sequences from large datasets has not been perceived as a limitation in the field of conotoxin research, the lack of a clear definition combined with the complexity of biological activities and toxicities has complicated the generation of well-reasoned regulations for research on, and access to, conotoxins (see Section 3.4).

\section{Conotoxin "Cures"-Scientific and Societal Benefits of Conotoxin Research}

\subsection{The Conotoxin Drug Ziconotide (Tradename Prialt ${ }^{\circledR}$ )}

$\omega$-Conotoxin MVIIA (or ziconotide) is arguably the most famous conotoxin discovered to date. First isolated from the venom of the magician cone, Conus magus, at the University of Utah in 1982 [26], it was developed as a drug for the treatment of intractable pain by the biotech company Neurex Corp, approved by the United States Food and Drug Administration (FDA) in 2004, and marketed as Prialt ${ }^{\circledR}$ (the primary alternative to morphine) (Table 2). The history of the discovery of $\omega$-conotoxin MVIIA 
has recently been reviewed in more detail elsewhere [35]. Here, we focus on the initial scientific goals that led to the discovery of $\omega$-MVIIA and the societal benefits of this conotoxin today.

Table 2. Overview of conotoxin drug leads.

\begin{tabular}{|c|c|c|c|c|}
\hline Conotoxin & Molecular Target & Clinical Indication & $\begin{array}{c}\text { Stage in } \\
\text { Development }\end{array}$ & Company \\
\hline $\begin{array}{l}\text { MVIIA (ziconotide, } \\
\text { Prialt }{ }^{\circledR} \text { ) }\end{array}$ & $\mathrm{Ca}_{\mathrm{v}} 2.2$ channel & $\begin{array}{l}\text { Refractory chronic } \\
\text { and cancer pain }\end{array}$ & Approved & $\begin{array}{c}\text { TerSera Therapeutics, } \\
\text { Riemser Pharma } \\
\text { GmbH, Eisai Co., Ltd. }\end{array}$ \\
\hline$\alpha$-RgIA4 (KCР-400) & $\begin{array}{c}\text { nAChR (subtype } \\
\alpha 9 \alpha 10)\end{array}$ & Neuropathic Pain & Pre-clinical (ongoing) & Kineta, Inc. \\
\hline $\begin{array}{c}\text { Mini-Ins } \\
\text { (conotoxin insulin } \\
\text { analog) }\end{array}$ & Insulin receptor & Type 1 diabetes & Pre-clinical (ongoing) & Monolog LLC \\
\hline $\begin{array}{l}\text { Contulakin-G } \\
(C G X-1160)\end{array}$ & Neurotensin receptor & Neuropathic Pain & $\begin{array}{c}\text { Phase I (on hold, } \\
\text { demise of company) }\end{array}$ & Cognetix, Inc. \\
\hline$\alpha-\mathrm{Vc} 1.1(\mathrm{ACV} 1)$ & $\begin{array}{c}\text { nAChR (subtype } \\
\alpha 9 \alpha 10)\end{array}$ & Neuropathic Pain & $\begin{array}{c}\text { Phase I } \\
\text { (discontinued, lack of } \\
\text { efficacy) }\end{array}$ & $\begin{array}{c}\text { Metabolic } \\
\text { Pharmaceuticals }\end{array}$ \\
\hline$\omega-C V I D$ & $\mathrm{Ca}_{\mathrm{v}} 2.2$ channel & Chronic Pain & $\begin{array}{c}\text { Phase II } \\
\text { (discontinued) }\end{array}$ & Amrad, Inc. \\
\hline x-MrIA (Xen2174) & $\begin{array}{l}\text { Norepinephrine } \\
\text { transporter }\end{array}$ & Postoperative pai & $\begin{array}{c}\text { Phase II } \\
\text { (discontinued) }\end{array}$ & Xenome, Inc. \\
\hline $\begin{array}{l}\text { Conantokin-G } \\
\text { (CGX-1007) }\end{array}$ & $\begin{array}{l}\text { NMDA receptor } \\
\text { (subtype NR2B) }\end{array}$ & $\begin{array}{l}\text { Intractable } \\
\text { Epilepsy }\end{array}$ & $\begin{array}{c}\text { Pre-clinical } \\
\text { (discontinued, } \\
\text { demise of company) }\end{array}$ & Cognetix, Inc. \\
\hline $\begin{array}{c}\text { K-PVIIA } \\
(\text { CGX-1051) }\end{array}$ & $\mathrm{K}_{\mathrm{v}} 1$ subfamily & Cardioprotection & $\begin{array}{c}\text { Pre-clinical } \\
\text { (discontinued, } \\
\text { demise of company) }\end{array}$ & Cognetix, Inc. \\
\hline
\end{tabular}

$\omega$-MVIIA was discovered as part of an initiative into understanding why the venom of fish-hunting cone snails could be paralytic. In fish, $\omega$-MVIIA was found to block neuromuscular transmission at the presynaptic terminus by inhibiting a specific voltage-gated calcium channel [36,37]. However, in the early 1980s, calcium channels had not been defined at a molecular level and it was uncertain how many different voltage-gated calcium channels were present in the vertebrate nervous system. The isolation of $\omega$-MVIIA and a related peptide from Conus geographus, $\omega$-GVIA, provided key pharmacological tools to define different types of voltage-gated calcium channels. Both peptides were selective for a calcium channel subtype that had not previously been recognized (initially known as the N-type calcium channel, and later as $\mathrm{Ca}_{\mathrm{v}} 2.2$ ). While exploring the potential biomedical applications of $\omega$-MVIIA, experiments conducted by Neurex Corp with a radiolabeled analog revealed specific binding to layers of the spinal cord dorsal horn previously established to be important for the perception of pain [38]. This finding paved the way for the subsequent development of $\omega$-MVIIA as an analgesic [39].

The commercial drug Prialt ${ }^{\circledR}$ is an exact synthetic copy of $\omega$-MVIIA. When approved by the FDA in 2004, Prialt was a welcome addition to the repertoire of anesthesiologists as an agent with a non-opioid mechanism. Unlike opioids, Prialt does not cause addiction or respiratory depression, but at high doses can lead to other severe, albeit not fatal, side effects, including psychomotor effects ranging from mild ataxia and auditory hallucinations (typically completely reversible with a small dose reduction) to more debilitating ataxia and psychosis. Furthermore, because Prialt acts by targeting $\mathrm{Ca}_{\mathrm{v}} 2.2$ channels expressed in the central nervous system, it must be administered intrathecally using an implanted pump. This is an invasive and relatively costly procedure that has been a barrier to more widespread use. Thus, clinically, Prialt was often used a last resort. However, due to the lack of availability of effective, non-opioid therapeutics, recent guidelines now encourage the use of Prialt as a first-line agent in various pain conditions including neuropathic and nociceptive pain [40]. 
Furthermore, Prialt has been increasingly used in combination with an intrathecal opioid, exploiting the potentially synergistic effect of Prialt and opioids in the treatment of refractory chronic and cancer pain [41].

\subsection{Conotoxin Drug Leads}

In addition to the clinical development of $\omega$-MVIIA several other conotoxins have been at various stages of development as drug leads for pain, epilepsy, heart disease, and diabetes (for recent reviews on these toxins see $[35,42-44]$ ). Table 2 provides an overview of these drug leads. Despite their promising therapeutic applications, none of these conotoxins has (yet) reached clinical approval. It is difficult to assess the underlying reasons for this because information on commercial developments of drug leads is typically not made accessible to the public when the development of a compound is discontinued (e.g., information on lack of efficacy in clinical trials, safety concerns, change in a company's development program, demise of a company, intellectual property disputes, etc.). Where known, we list the current development status of conotoxin drug leads and the reason for why past development efforts were halted (Table 2).

Regardless of their drug development status, many of these toxins have become valuable pharmacological and biomedical tools for the study of signaling pathways important in health and disease.

\subsection{Diagnostic Tool}

One hallmark feature of conotoxins is their target specificity for closely related subtypes of receptors and ion channels. The selectivity profile of $\omega$-conotoxin GVIA from the venom of Conus geographus, a homolog of the approved drug Prialt, led to its development as a diagnostic tool for Lambert-Eaton myasthenic syndrome (LEMS). LEMS is an autoimmune disorder, which results in muscle weakness, and is associated with lung cancer. LEMS is caused by the production of antibodies against presynaptic voltage-gated calcium channels (VGCCs), which results in the inhibition of acetylcholine release at the neuromuscular junction [45-47]. While it has historically been difficult to differentiate LEMS from symptomatically related disorders, in 1989 Sher and coworkers showed that antibodies against VGCCs produced in LEMS could immunoprecipitate ${ }^{125} \mathrm{I}-\omega$-conotoxin GVIA-bound N-type VGCCs $\left(\mathrm{Ca}_{\mathrm{v}} 2.2\right)$, which are elevated in about half of LEMS patients $[45,48]$. This laid the basis for a diagnostic radio immunoprecipitation assay to differentiate LEMS from similar disorders, such as myasthenia gravis. By labeling solubilized cell membrane expressing $\mathrm{Ca}_{\mathrm{v}} 2.2$ with ${ }^{125}$ I-labeled $\omega$-conotoxin GVIA, and exposing this to LEMS patient serum, antibodies against $\mathrm{Ca}_{\mathrm{v}} 2.2$ can bind the receptor-conotoxin complex. These are then precipitated, and the radioactivity can then be detected, indicating that the patient serum contains $\mathrm{Ca}_{\mathrm{v}} 2.2$ antibodies. This diagnosis was later improved by the use of a different conotoxin that binds P/Q-type VGCCs $\left(\mathrm{Ca}_{\mathrm{v}} 2.1\right)$, $\omega$-conotoxin MVIIC. Antibodies against $\mathrm{Ca}_{\mathrm{v}} 2.1$ are elevated in about $85 \%$ of LEMS patients [49,50]. Differentiating these disorders is critical for guiding clinical care [51]. The emergence of medically relevant diagnostic tools provides an important example for the societal benefits of conotoxin research.

\subsection{Cosmetics}

Similarly to botulinium toxin (Botox ${ }^{\circledR}$ ), conotoxins that have myorelaxant properties can be developed as anti-wrinkle creams or injectable formulations. One such conotoxin is $\mu$-CIIIC, originally isolated from the fish-hunting cone snail Conus consors as part of the European Commission-funded CONCO project ("CONCO: the cone snail genome project for health"). $\mu$-CIIIC preferentially blocks the skeletal muscle sodium channel, $\mathrm{Na}_{\mathrm{v}} 1.4$, and the neuronal sodium channel $\mathrm{Na}_{\mathrm{v}} 1.2$ [52]. Due to the blocking of $\mathrm{Na}_{\mathrm{v}} 1.4$, it can act as a myorelaxant. $\mu$-CIIIC was initially investigated as a drug for the treatment of pain and as a local anesthetic but is now sold as the active ingredient in a non-prescription cosmetic anti-wrinkle product under the name "XEPTM-018". 


\subsection{Research Tools}

Conotoxins that target mammalian receptors are often selective for certain receptor subtypes, or subunit compositions. This feature renders conotoxins excellent tools for a plethora of studies in the areas of pharmacology, neuroscience, biochemistry, and structural biology. Table 3 lists a small number of these conotoxins, and examples of their use in basic biology and biomedical research. There is of course overlap with clinically developed conotoxins (Table 2), which are also often used as research tools. For instance, $\omega$-conotoxin MVIIA (the drug Prialt), has been used as a tool compound in thousands of studies.

Another conotoxin that has been extensively used as a research tool in the scientific literature (> 3000 publications) is $\omega$-conotoxin GVIA, a potent and selective blocker of the presynaptic N-type calcium channels, $\mathrm{Ca}_{\mathrm{v}} 2.2$. The $\mathrm{Ca}_{\mathrm{v}} 2.2$ channels play a crucial role in neurotransmitter release in response to action potentials in the kidneys, where they regulate the dilation of arteries, and in the heart, where they regulate cardiac excitability [53-55]. Hence, $\omega$-conotoxin GVIA has been used extensively in numerous studies of various topics, including neurotransmission, pain, cardiology, epilepsy, renal function, and nuclear signaling (selected references in Table 3).

Another example is the $\alpha$-conotoxin, ImI, from the vermivorous Conus imperialis (as well as the subsequently discovered $\alpha$-conotoxin, ImII [56]). ImI and ImII are inhibitors of the neuronal $\alpha 7$ subtype of the nAChRs [57]. These toxins, like most other subtype- or subunit-selective conotoxins, have been used to elucidate the importance of receptor subunits in numerous biological- and pathophysiological studies [58-60]. However, they have also seen other more specialized uses. For instance, in a 2014 study Heghinian and co-workers used several different $\alpha$-conotoxins to perform structurally guided mutations in the $D$. melanogaster $\alpha 7 \mathrm{nAChR}$, allowing this receptor to display similar selectivity for various conotoxins as the mammalian counterpart. This, in turn, resulted in D. melanogaster cholinergic synapses that mimic the synaptic behavior of vertebrate synapses, improving the suitability of these mutant flies as a tool for in vivo drug discovery [61].

In a 2015 study, Lin and co-workers utilized the specificity of $\alpha$-ImI for cellular targeting of the chemotherapy drug, paclitaxel [62]. The authors showed that linking paclitaxel-containing micelles to $\alpha-\operatorname{ImI}$ significantly decreased the mass of tumors in mice when compared to either unlinked paclitaxel-filled micelles or free paclitaxel. In addition, they observed a lower systemic toxicity of the $\alpha$-ImI-linked micelles.

In addition, several conotoxins have served as tools in structural biology to elucidate specific receptor binding sites or mechanisms of receptor activation. For instance, the X-ray crystal structure of the conotoxin con-ikot-ikot from Conus striatus [63] in complex with the GluR2 AMPA receptor subunit revealed the molecular mechanism underlying receptor activation [64]. Another example is the conotoxin Con-Insulin G1 from Conus geographus that revealed a minimum binding motif of insulin at the human insulin receptor [65].

Conotoxins undergo post-translational processing (folding and modification) in the ER and Golgi prior to packaging and secretion into the lumen of the venom gland. Due to their small size, chemical diversity, and high degree of post-translational modifications, conotoxins are ideal candidates to study general principles of peptide folding, modification, and secretion. Several conotoxins have been repeatedly used as model substrates for studies into enzyme-assisted peptide biosynthesis and folding, such as $\alpha$-GI [66,67], $\mu$-SmIIIA [68,69], and conantokin-G [70,71].

Lastly, conotoxins are among the most rapidly evolving gene products known in nature and have served as tools in a diverse range of studies on the effects of feeding ecology, prey taxa, dietary breadth, age and geographical heterogeneity on the evolution of venom genes [72-76], and studies on the role of gene duplication and positive selection on venom gene expression and diversification [77-79]. 
Table 3. Examples of conotoxins used as research tools.

\begin{tabular}{|c|c|c|c|}
\hline Conotoxin & Target & Feature & Useful in Field(s) of Research \\
\hline $\begin{array}{l}\alpha-\mathrm{GI}, \mu-\mathrm{SmIIIA}, \\
\text { Conantokin-G }\end{array}$ & Various targets & $\begin{array}{l}\text { Substrates for enzymes } \\
\text { involved in peptide } \\
\text { biosynthesis }\end{array}$ & $\begin{array}{l}\text { Elucidating peptide biosynthesis } \\
\text { and folding [68-70] }\end{array}$ \\
\hline$\alpha$-ImI & $\alpha 7 \mathrm{nAChR}$ & Subtype selectivity [56] & $\begin{array}{c}\text { Targeted drug delivery in } \\
\text { cancer [62], engineering } \\
\text { D. melanogaster as better human } \\
\text { disease model [61], chromaffin cell } \\
\text { signaling [57] }\end{array}$ \\
\hline$\alpha-\mathrm{MII}$ & nAChR & Subtype selective [80] & $\begin{array}{c}\text { Inflammation [81], reward and } \\
\text { addiction }[82,83]\end{array}$ \\
\hline$\alpha-V_{c} 1.1$ and $\alpha-\operatorname{Rg} 1 \mathrm{~A}$ & $\alpha 9 \alpha 10 \mathrm{nAChR}$ & Subtype selective $[84,85]$ & $\begin{array}{l}\text { Neuropathic pain and } \\
\text { inflammation [86-88], } \\
\text { immunology [89-91] }\end{array}$ \\
\hline Con-ikot-ikot & AMPA receptor & $\begin{array}{l}\text { Disrupts desensitization, } \\
\text { stabilizes open } \\
\text { conformation }[63,64]\end{array}$ & Receptor crystallization [64] \\
\hline Con-Insulin G1 & Insulin receptor & $\begin{array}{l}\text { Minimized binding motif } \\
\text { at the insulin receptor [65] }\end{array}$ & $\begin{array}{l}\text { Receptor binding and drug } \\
\text { design [92] }\end{array}$ \\
\hline к-PVIIA & $\begin{array}{l}\text { Voltage-gated } \mathrm{K}^{+} \\
\text {channels }\end{array}$ & $\begin{array}{l}\text { Voltage-sensitive } \\
\text { binding/blocking of } \\
\text { voltage-gated } \\
\text { K-channels [15] }\end{array}$ & $\begin{array}{c}\text { Cancer [93], cardioprotection in } \\
\text { ischemia [94] }\end{array}$ \\
\hline кM-RIIIJ & $\begin{array}{l}\text { Voltage-gated } \mathrm{K}^{+} \\
\text {channels }\end{array}$ & Subtype selectivity $[95,96]$ & $\begin{array}{c}\text { Neuronal profiling }[5,6,97,98] \text {, } \\
\text { channel subtype expression } \\
\text { profiling }[96,99]\end{array}$ \\
\hline$\omega$-GVIA & $\begin{array}{l}\text { Voltage-gated } \\
\mathrm{Ca}^{2+} \text { channels }\end{array}$ & Subtype selective $[37,99]$ & $\begin{array}{l}\text { Neurotransmission [100-102], } \\
\text { pain [103], cardiology [55], } \\
\text { epilepsy [104], renal function } \\
\text { [105], nuclear signaling [106] }\end{array}$ \\
\hline$\omega$-MVIIC & $\begin{array}{l}\text { Voltage-gated } \\
\mathrm{Ca}^{2+} \text { channels }\end{array}$ & $\begin{array}{l}\text { Inhibits various subtypes } \\
\text { broadly }[107,108]\end{array}$ & $\begin{array}{c}\text { Epilepsy [109], long-term } \\
\text { depression [110], pain }[111,112]\end{array}$ \\
\hline
\end{tabular}

\subsection{Conotoxin Research-A View toward the Future}

Recent advances in throughput and sensitivity of next-generation DNA and peptide sequencing have resulted in a massive increase in the rate of conotoxin discovery (for example [34,113]). This is unlikely to decrease any time soon given that the cost of sequencing continues to fall. In combination with the generation of easier, less computationally heavy bioinformatic tools for data analysis, conotoxin discovery can now be done without the need of expensive or highly specialized equipment. The increasing rate of conotoxin discovery is being met with advances in methodologies for conotoxin production (for example [114-116]), high-content target screening and identification (for example [117-119]), and with a newly sparked interest in peptide-based drug development by the pharma industry [120]. We anticipate that this combination will lead to the development and design of many more conotoxin-based biomedical tools and pharmacological agents in the future.

\section{Conotoxin "Curses"-Biosecurity Concerns}

\subsection{Cone Snail Envenomations and Human Fatalities}

From the very first report of a human fatality from a cone snail sting $\approx 350$ years ago, through to 2017, 141 cases of human envenomations have been recorded, of which 36 were fatal [121]. No human fatalities have been reported for the past 20 years. Most, if not all, of the 36 human fatalities caused by 
cone snail stings have been attributed to a single species, Conus geographus [121]. All of these were accidental, and there have been no reports of the use of cone snail venom as a weapon for murder.

In humans, symptoms from cone snail envenomations vary depending on several factors, including cone snail species. Often, pain or numbness is reported, but symptoms can include edema, vision impairment, fatigue and faintness, dyspnea, loss of reflexes, and nausea. Some victims have noticed a burning sensation at the site of the sting, while others have reported that the sting itself initially went unnoticed. Subsequently, reports of faintness, palpebral ptosis, dysphagia, as well as vision and speech impairment are common in more severe cases, though in some cases no obvious symptoms have been reported prior to the onset of muscle paralysis, which in the worst case can lead to death due to respiratory or cardiac arrest within a few hours [122-124]. No effective antivenom exists against cone snail venom.

While the venom of a small subset of the $\approx 800$ species of cone snails is toxic to humans, the number of human envenomations by these animals pales in comparison to those reported for other venomous animals. Snake bites undoubtedly comprise the largest contribution of serious human envenomations by any group of animals. While exact data can be difficult to obtain, the World Health Organization estimates that $\approx 2.7$ million people are envenomated by snakes every year, resulting in 81,000-138,000 deaths per year, and 400,000 permanent disabilities, including amputations [125]. The large number of deaths from snake bites result, in part, from a much larger rate of human-snake encounters. Nevertheless, it is clear that snake envenomations present a significantly larger concern to human health and life, compared to cone snails.

Another large contributor to human envenomations are scorpions, with an estimated 1.2 million global envenomations, and more than 3250 deaths each year [126]. One of the most venomous stings, the eastern red scorpion Hottentotta tamulus, has an estimated fatality rate of $\approx 30 \%$ when untreated. Similarly to cone snails, no effective antivenom exists for $H$. tamulus venom, though treatment with the anti-hypertension drug prazosin can lower this fatality rate to $2-4 \%[127,128]$.

As with cone snails, other venomous animals have also been an important source of biological, and biomedical research, research tools, as well as drugs and drug leads. Snake venom has provided several clinically important drugs, including blood pressure medication, coagulants, and anticoagulants [129-131]. Numerous scorpion venom components are likewise being investigated for biomedical uses, including novel peptide antimicrobial drugs [132].

\subsection{Fictional Use of Conotoxins as Bioweapons}

As envenomation by some species can be deadly, cone snails and their toxins have gained notoriety, both in national biodefense considerations (see Section 3.4), as well as in fiction. Some of these have recently been reviewed elsewhere [121,133].

For instance, in the Michael Crichton novel "The Lost World" (the sequel to "Jurassic Park"), as well as in the movie and video game adaptations of the novel, the "Lindstradt air gun", a gun shooting a dart containing "enhanced venom" from the cone snail Conus purpurascens is used to kill or paralyze dinosaurs. In the movie, Conus purpurascens venom is described as the most powerful neurotoxin in the world that acts within 1/2000th of a second, which is stated to be faster than the velocity of nerve conduction.

In a 1972 episode of the television show Hawaii five-0 (season 4, episode 20: "Cloth of Gold"), a Conus textile, also called the "cloth of gold", is intended to be used as a murder weapon. Instead it ends up being used as a tool for suicide by the main antagonist who presses it against his throat and is stung.

The Danish/Swedish television show, "Broen" ("The Bridge", season 4, episode 5), featured the venom of Conus geographus (although an image of Conus textile was shown) as a weapon for murder. The toxin used was allegedly manufactured in a conotoxin production facility in Hamburg, Germany. 
Another example is an episode of the animated British children's show "Octonauts" (season 3, episode 3) that featured a cone snail shooting poison-loaded harpoons at crew members after being lost inside an underwater vessel.

Conotoxins have also appeared in several written murder mysteries, such as in James Patterson's 2018 thriller "Murder in Paradise" or the novel "Murder on the Mataniko Bridge" by Ann Kengalu.

\subsection{Conotoxin Toxicity}

Contrary to their appearance as powerful murder weapons in fiction, no real-life incident for the nefarious use of a cone snail, its venom or toxin components has ever been reported. In this section, we report on the toxicity of some conotoxins in mammals that inspired both their use as weapons in fiction, and the introduction of regulatory measures for scientists working with conotoxins.

Due to the way conotoxins were traditionally identified (i.e., by behavioral bioassays in mice, see Section 1.2), the toxins that are the most potent in mammals were typically among the first to be identified $[11,26,27]$. As discussed above, these include a toxin from C. geographus, $\alpha$-conotoxin GI, a potent inhibitor of nicotinic acetylcholine receptors of the neuromuscular junction [134-136] (Table 4). $\alpha$-conotoxin GI significantly contributes to the comparably high fatality rate of $C$. geographus envenomations where it is believed to induce muscle paralysis and, ultimately, respiratory arrest due to paralysis of the diaphragm [137]. This toxin was described more than 40 years ago, and yet, to our knowledge, no incidents have ever been reported of its misuse. On the contrary, $\alpha$-conotoxin GI been a valuable research tool in neurosciences and biochemistry (Table 3). As with all cone snail species, the venom of $C$. geographus contains more than 100 different toxins, the majority of which are not considered harmful to humans. As with $\alpha$-conotoxin GI, numerous other $C$. geographus toxins have been valuable as drug leads and biomedical tools as well as one diagnostic agent (see Sections 2.2, 2.3 and 2.5).

Since conotoxins comprise a large and diverse class of compounds with many different biomolecular targets in various species, the mammalian toxicity of different conotoxins likewise covers a range of orders of magnitude. The median lethal dose $\left(\mathrm{LD}_{50}\right)$ of $\alpha$-conotoxin GI is $12 \mu \mathrm{g} / \mathrm{kg}$ when injected intraperitoneally (IP) in mice [11]. Indeed, several conotoxins in the $\alpha$-conotoxin family that target muscle-type nicotinic acetylcholine receptors of the neuromuscular junction, are quite potent toxins in mammals. However, this group forms a very small subset of $\alpha$-conotoxins (most target neuronal nAChR subtypes and have very little to no toxicity in mammals) and a minuscule percentage of all conotoxins. For the vast majority of other conotoxins, the toxicity in mammals is so low that no $\mathrm{LD}_{50}$ has ever been determined. This not only includes many toxins from worm- or snail hunting species that have little to no effect in vertebrates, but also numerous toxins from fish hunters. For instance, the venom of $C$. geographus contains a vasopressin-like toxin (conopressin-G) that elicits a grooming behavior in mice when injected intracerebrally [24], and insulin-like toxins (coninsulins), that are used by the snail to induce low blood sugar in fish prey but activate the mammalian insulin receptor at much lower potency than human insulin [138]. As stated above, even within the family of $\alpha$-conotoxins, most toxins have very low to no toxicity in mammals. For instance, $\alpha$-conotoxin GIC, also from C. geographus, targets neuronal nAChRs, does not block human neuromuscular nAChR subunit compositions in electrophysiological assays, nor do mice display any motor deficits or paralysis when injected with up to $5 \mathrm{nmol}$ IP (corresponding to $>250 \mu \mathrm{g} / \mathrm{kg}$ ) [139].

While certain conotoxins are indeed toxic to humans, these toxins are significantly less potent than certain toxins produced in other animals (see Table 4). For instance, even the most lethal conotoxin is more than one order of magnitude less potent than both textilotoxin, a protein toxin from the eastern brown snake, Pseudonaja textilis, as well as ciguatoxins and maitotoxins, which are produced by various dinoflagellate species.

Furthermore, conotoxins appear to only be toxic when injected. While not every route of administration has been described, attempts have been made to improve the oral activity of conotoxin drug leads. An example is the $\alpha$-conotoxin Vc1.1, where numerous modifications were tested in order 
to increase its oral bioactivity. The analog obtained with the highest oral bioactivity was still $\approx 1000$ fold less potent when administered orally, than when injected $[86,140]$.

Table 4. Comparison of the median lethal dose $\left(\mathrm{LD}_{50}\right)$ of different toxins and toxic substances.

\begin{tabular}{|c|c|c|c|c|c|c|}
\hline Toxin & $\begin{array}{l}\text { LD50 in } \\
\text { Mice } \\
(\mu \mathrm{g} / \mathrm{kg})\end{array}$ & $\begin{array}{c}\text { Route of } \\
\text { Administration }\end{array}$ & $\begin{array}{l}\text { Type of } \\
\text { Toxin }\end{array}$ & Source & $\begin{array}{l}\text { Known } \\
\text { Antivenom/ } \\
\text { Antidote }\end{array}$ & Reference \\
\hline$\alpha$-conotoxin GI & 12 & IP & Peptide & Conus geographus & No & [11] \\
\hline$\omega$-conotoxin GVIA & $\approx 60$ & IP & Peptide & Conus geographus & No & [141] \\
\hline Textilotoxin & 1 & IP & Protein & Pseudonaja textilis & Depends * & [142] \\
\hline Volkensin & $1.38-1.73$ & IP & Protein & Adenia volkensii & No & [143] \\
\hline Ciguatoxin-1 & 0.25 & IP and oral & $\begin{array}{l}\text { Polycyclic } \\
\text { poylethers }\end{array}$ & Various dinoflagellates & No & [144] \\
\hline Maitotoxin & 0.13 & IP & $\begin{array}{l}\text { Polycyclic } \\
\text { poylethers }\end{array}$ & Various dinoflagellates & $\mathrm{No}^{+}$ & [145] \\
\hline Palytoxin & 0.15 & IV & $\begin{array}{l}\text { Polycyclic } \\
\text { poylethers }\end{array}$ & $\begin{array}{c}\text { Palythoa corals and } \\
\text { dinoflagellates (or bacteria } \\
\text { living on these) }\end{array}$ & No & [146] \\
\hline Batrachotoxin & 2 & SC & Alkaloid & Various beetles, birds, and frogs & No & [147] \\
\hline Saxitoxin & 10 & IP & Alkaloid & Various marine dinoflagellates & $\begin{array}{l}\text { In guinea } \\
\text { pigs } \#\end{array}$ & [148] \\
\hline Tetrodotoxin & 8 & IV & Alkaloid & $\begin{array}{l}\text { Various marine bacteria (e.g., } \\
\text { Pseudoalteromonas tetraodonis) } \\
\text { symbiotically living with } \\
\text { numerous marine animals, } \\
\text { e.g., Tetraodontidae fish, } \\
\text { Hapalochlaena octopodes, and } \\
\text { Naticidae snails }\end{array}$ & $\mathrm{No}^{+}$ & [149] \\
\hline
\end{tabular}

+ Supportive treatment provided [150]. ${ }^{*}$ After initial binding phase completed, antivenom seems to have no effect [151,152]. \# 4-Aminopyridine (marketed as Ampyra in the US, and used to manage symptoms of multiple sclerosis) has been shown to reverse the effect of saxitoxin poisoning in guinea pigs [153].

\subsection{Past and Current Regulations of Research on Conotoxins}

Worldwide, various governing bodies are responsible for maintaining lists of regulated substances that are deemed biosecurity concerns. Items on these regulatory lists are subject to certain restrictions in their export and use, including in research. These lists contain various pathogens (e.g., Ebola virus, sheeppox virus) but also include toxins of biological origin. Most of these toxins have a well-defined chemical identity and biological activity, e.g., tetrodotoxin, botulinum toxin, or T2-mycotoxin. However, for conotoxins, this is not the case, and the term "conotoxin" or "conotoxins" is used without additional classification. For example, at the time of writing, the European Union (EU) includes "conotoxin" as a controlled substance [154] and Australian regulations cover "conotoxins" [155], both of which are virtually identical to how the United States regulated conotoxins prior to a 2012 revision. Thus, these two lists not only include conotoxins that have toxicity in vertebrates, but also those that elicit little or no physiological response in vertebrates and those with unknown biological activity. Given the chemical, structural, and biological diversity of conotoxins (see Section 1.1) regulating conotoxins as a single entity is clearly problematic. It is worth noting that to the best of our knowledge, no regulatory agency has ever had "snake toxins" or "scorpion toxins" as a regulated substance in the same manner as "conotoxins". Neither does any country, to the best of our knowledge, regulate any of the specific components of any animal venoms, even ones that are more potent toxins in mammals than any conotoxin (see Table 4 for examples). Without a clear definition of the term "conotoxin", as currently the case in many countries, interpretation is often left to the individual evaluating a given case, who is typically not an expert in the field.

To address this, some countries have more narrowly defined their classification of regulated conotoxins. For example, until 2012, the select agent list in the United States included "conotoxins". This has since been revised to only include the paralytic $\alpha$-conotoxins containing a very distinct sequence pattern, which corresponds to the sequence motifs found in the conotoxins that block muscle-type 
nicotinic acetylcholine receptors ([156]; "Short, paralytic alpha conotoxins containing the following amino acid sequence $X_{1} C C X_{2} P A C G X_{3} X_{4} X_{5} X_{6} C X_{7}$ where $C=$ Cysteine residues with the 1 st and $3 r d$ Cysteine, and the 2 nd and 4 th Cysteine forming specific disulfide bridges; $X_{1}=$ any amino acid(s) or Des-X; $X_{2}=$ Asparagine or Histidine; $P=$ Proline; $A=$ Alanine $; G=$ Glycine; $X_{3}=$ Arginine or Lysine; $X_{4}=$ Asparagine, Histidine, Lysine, Arginine, Tyrosine, Phenylalanine or Tryptophan; $X_{5}=$ Tyrosine, Phenylalanine, or Tryptophan; $X_{6}=$ Serine, Threonine, Glutamate, Aspartate, Glutamine, or Asparagine; $X_{7}=$ Any amino acid(s); "Des $X "$ = "an amino acid does not have to be present at this position."). This narrower definition was also recently adopted by the Danish Center of Biosecurity and Biopreparedness (CBB) [157].

In 1985, the "Australia Group" was formed as an informal arrangement aimed at allowing members to harmonizing export, while minimizing the risk of this export aiding in chemical and biological weapon proliferation [158]. At the time of writing, the Australia Group has 44 members, including Australia, New Zealand, the United States, Argentina, Mexico, Japan, the Republic of Korea, the United Kingdom, Switzerland, and members of the European Union. Conotoxins are listed as biological agents, thus requiring members to control their international trade with the exception of medical or clinical formulations of conotoxins designated for human use.

The exact implementation of the regulations, in regard to research activities utilizing conotoxins, varies in different countries, but typically researchers are allowed to work with threshold amounts (often $100 \mathrm{mg}$ is used), while being subject to lower regulatory requirements for handling, training, and/or reporting to authorities, whereas higher amounts of conotoxin are typically subject to more stringent restrictions and requirements. Where regulatory agencies have differentiated various conotoxins, this typically applies to a very select group of paralytic and potent toxins in mammals, such as the paralytic $\alpha$-conotoxins. If differences between conotoxins are not specified, these limitations are typically interpreted to mean that even small amounts of any conotoxin are regulated in this manner, regardless of the toxicity of the specific conotoxin in question.

It is interesting to note that the crude cone snail venom, even from the most venomous species, has never been regulated. Only "conotoxin" components of the venom are regulated, even in cases where the term "conotoxins" is used to encompass every single component of the venom. This is despite the fact that the venom components elicit a synergistic effect, in fact being more potent as crude venom than as the individual components that are regulated [15,159].

\subsection{Potential Use of Conotoxins as Bioweapons}

Although, to our knowledge, there has not been a single incident on the use of cone snail venom or conotoxins outside of legitimate research and drug development programs, the regulatory measures described in the previous Section 3.4 reflect concerns about the potential misuse of conotoxins in bioterrorism.

One such concern is that conotoxins could potentially be aerosolized and thus more easily spread and inhaled by potential victims. The bioavailibilities upon pulmonary inhalation greatly varies between different compounds [160-163] making it difficult to predict whether any conotoxin would retain toxicity in an aerosolized form. If indeed they did, this would provide an alternate route of administration. However, the toxin would still need to be formulated for aerosolization purposes, and formulating peptides for aerosol delivery is not trivial. Producing the appropriate particle sizes, as well as the being able to retain peptide integrity during the process remains challenging [164].

Another potential concern is that some conotoxins could be injected thereby acting as a murder weapon. However, this also applies to many other biological and non-biological compounds that are lethal when directly injected into the human body, many of which have never been regulated.

The small amount needed for some conotoxins could potentially render them difficult to detect, complicating the determination of the cause of death. The pharmacokinetics of conotoxins in humans are not well described. It has been reported that for $\alpha$-conotoxin GI, no breakdown was detected after a 3-h incubation in human plasma [165], and for $\alpha$-conotoxin MII, more than $60 \%$ remained after $24 \mathrm{~h}$ of incubation in human plasma [166], though the in vivo clearance of these and other conotoxins could 
be much faster due to metabolism outside of systemic circulation [167]. While modern forensic testing methods are able to detect peptide concentration in plasma of $\approx 0.1$ parts-per-billion [168], it is possible that a conotoxin could metabolize beyond this limit before an autopsy would be performed. A further and likely more pressing concern could be that no antivenom exists. This means that even if a victim could receive care in time, life-saving medical interventions are limited to supportive care (for example, for $\alpha$-conotoxin GI mouth to mouth or mechanical ventilation can be performed until the paralysis wears off). This, however, is also true for numerous compounds that are not regulated, several of them being more potent than any conotoxin (see Table 4).

Another avenue for potentially using conotoxins as bioweapons could be their incorporation into the genomes of pathogenic viruses and bacteria genomes in order to enhance their deadliness. According to an interview with a former scientist in the United States senate a program of such nature was allegedly carried out in the Soviet Union. This program allegedly led to the generation of a smallpox virus that carried conotoxin sequences before it was ultimately terminated [169]. As stated in the interview these conotoxins contained two specific cystine bridges and, thus, were likely $\alpha$-conotoxins. While this report could have led to the strict regulations regarding conotoxin research, it should be noted that many other toxins could be used in such a manner and research on dangerous pathogens, including the smallpox virus, is already strictly regulated.

In 2017, El-Aziz and co-workers published a method for in vivo neutralization of toxic peptides using DNA oligonucleotides [170]. As a proof of concept, they used $\alpha$-conotoxin PrXA from Conus parius, a fast acting and potent toxin targeting the nAChRs of the skeletal muscles. They showed that the oligonucleotides ("adaptamers") could efficiently counteract the binding to receptors, inhibition of diaphragm contraction, and death induced by this conotoxin in mice. While not yet available for clinical use, the World Health Organization has classified envenomations as category A (the highest priority concern available), mostly due to snake bites. Since this approach could also be useful for toxins from other animals, including snakes, these promising efforts could lead to the generation of effective medical treatment options in the future.

\section{Concluding Remarks}

\subsection{Concluding Remarks on Conotoxin "Cures"}

Since the dawn of conotoxin research $\approx 60$ years ago $[6,171,172]$, the number of new conotoxins being identified has exploded. Through the decades, their increasing chemical and pharmacological diversity became apparent and, to date, $>5000$ research articles have been published in this field of research. Furthermore, conotoxins have been used as tools in thousands of additional research studies, many of which could only be conducted due to the unique properties of certain conotoxins. From a basic understanding of receptor subunit compositions, receptor structures, and peptide folding and expression, to more physiological studies on such diverse topics as epilepsy, inflammation, cancer, pain, cardiology, renal function, and addiction (see Table 3), and even clinical studies and an FDA approved drug (see Table 2), these peptides have already provided immense benefits to basic and applied research and society. With the advances in genomics sequencing, the number of available conotoxin sequences is rapidly increasing. Every new sequence is a new opportunity for furthering research into novel biology, as well as clinical treatments. As long as researchers can use these valuable tools in their research, novel discoveries will continue for many more decades to come.

\subsection{Concluding Remarks on Conotoxin "Curses"}

A few select conotoxins are indeed toxic to humans, but the vast majority are not. It seems self-evident that the harmless conotoxins should not be subject to regulations. However, here we argue that even for the more potent toxins, regulations on researchers are unlikely to prevent their use in bioterrorism, but instead will impede research that, as outlined above, provides many impactful benefits. As we have explained, even the most potent conotoxins appear to be poor candidates for the 
development of biological weapons (see Section 3.5). Moreover, knowledge of toxin sequences and their synthesis has been publicly available for decades, and the reagents and equipment needed are, to the best of our knowledge, not regulated. In fact, some of these toxins can be readily purchased from commercial providers. However, as discussed, the actual formulation of conotoxins for an aerosol delivery is likely to prove challenging, and it is unclear whether conotoxins would even be bioavailable in such a formulation. With cheap, easy alternatives readily available and proven effective (e.g., phosgene gas), there would seem to be little incentive to pursue this. Consider too, that if successful, recent efforts in developing oligonucleotide-based blockers of peptide toxins may provide broadly applicable treatments. This would further lower the potential of conotoxins as bioweapons. Likewise, concerns about using conotoxins as injectable weapons, while possible, seem largely irrelevant outside of fiction, considering the plethora of other toxins or toxic substances that could easily replace conotoxins in such a scenario.

\subsection{Suggestions}

First, the lack of a clear definition of "conotoxin" or "conotoxins" in legislative work is highly problematic. At the very least, a clear distinction should be made between different conotoxins. If, after a careful consideration of the available literature, any regulatory authority still sees a reason to keep certain conotoxins on the list of potential bioweapon threats, it is essential that these are clearly differentiated from other conotoxins.

Second, it is our opinion that listing even the most potent toxins will have little effect in regard to their potential use in bioterrorism. As discussed, toxin sequences and information on synthesis and recombinant production are publicly available and have been for decades. Limiting the use of these toxins in research is unlikely to reduce a potential bioterror threat. Instead, it is a barrier to research in this important field.

Funding: B.M.O. and M.Y. acknowledges funding from the US National Institutes of Health (GM122869), and JMM from GM136430, GM103801 and US Department of Defense W81XWH170413 (to BMO and JMM). L.E. acknowledges funding from the Independent Research Fund Denmark | Technology and Production Sciences (7017-00288), and H.S.-H. acknowledges funding from the Velux Foundation (Villum grant 19063).

Conflicts of Interest: J.M.M., B.M.O. and H.S.-H. hold patents on some of the conotoxins listed in this review.

\section{References}

1. Abdelkrim, J.; Aznar-Cormano, L.; Fedosov, A.E.; Kantor, Y.I.; Lozouet, P.; Phuong, M.A.; Zaharias, P.; Puillandre, N. Exon-Capture-Based Phylogeny and Diversification of the Venomous Gastropods (Neogastropoda, Conoidea). Mol. Biol. Evol. 2018, 35, 2355-2374. [CrossRef] [PubMed]

2. Puillandre, N.; Bouchet, P.; Duda, T.F., Jr.; Kauferstein, S.; Kohn, A.J.; Olivera, B.M.; Watkins, M.; Meyer, C. Molecular phylogeny and evolution of the cone snails (Gastropoda, Conoidea). Mol. Phylogenetics Evol. 2014, 78, 290-303. [CrossRef] [PubMed]

3. Fleming, C.J. 1822, taxID: 14107. MolluscaBase. Available online: http://molluscabase.org/ (accessed on 14 July 2020).

4. World Register of Marine Species (WoRMS), tax ID 14107. Available online: https://www.marinespecies.org (accessed on 14 July 2020).

5. Puillandre, N.; Duda, T.F.; Meyer, C.; Olivera, B.M.; Bouchet, P. One, four or 100 genera? A new classification of the cone snails. J. Molluscan Stud. 2014, 80. [CrossRef] [PubMed]

6. Kohn, A.J.; Saunders, P.R.; Wiener, S. Preliminary studies on the venom of the marine snail. Conus. Ann. N. Y. Acad. Sci. 1960, 90, 706-725. [CrossRef]

7. Neves, J.L.; Lin, Z.; Imperial, J.S.; Antunes, A.; Vasconcelos, V.; Olivera, B.M.; Schmidt, E.W. Small Molecules in the Cone Snail Arsenal. Org. Lett. 2015, 17, 4933-4935. [CrossRef]

8. Safavi-Hemami, H.; Foged, M.M.; Ellgaard, L. Evolutionary Adaptations to Cysteine-Rich Peptide Folding. In Oxidative Folding of Peptides and Proteins; Feige, M.J., Ed.; Royal Society of Chemistry: London, UK, 2018. 
9. Puillandre, N.; Koua, D.; Favreau, P.; Olivera, B.M.; Stocklin, R. Molecular phylogeny, classification and evolution of conopeptides. J. Mol. Evol. 2012, 74, 297-309. [CrossRef]

10. Olivera, B.M.; Safavi-Hemami, H.; Horvarth, M.P.; Teichert, R.W. Conopeptides, Marine Natural Products from Venoms: Biomedical Applications and Future Research Applications. In Marine Biomedicine: From Beach to Bedside; Baker, B.J., Ed.; CRC Press: Boca Raton, FL, USA, 2015; ISBN 9780367575304.

11. Cruz, L.J.; Gray, W.R.; Olivera, B.M. Purification and properties of a myotoxin from Conus geographus venom. Arch. Biochem. Biophys. 1978, 190, 539-548. [CrossRef]

12. Fainzilber, M.; Nakamura, T.; Lodder, J.C.; Zlotkin, E.; Kits, K.S.; Burlingame, A.L. Gamma-Conotoxin-PnVIIA, a gamma-carboxyglutamate-containing peptide agonist of neuronal pacemaker cation currents. Biochemistry 1998, 37, 1470-1477. [CrossRef]

13. Shon, K.J.; Grilley, M.M.; Marsh, M.; Yoshikami, D.; Hall, A.R.; Kurz, B.; Gray, W.R.; Imperial, J.S.; Hillyard, D.R.; Olivera, B.M. Purification, Characterization, Synthesis, and Cloning of the Lockjaw Peptide from Conus purpurascens Venom. Biochemistry 1995, 34, 4913-4918. [CrossRef]

14. Jimenez, E.C.; Shetty, R.P.; Lirazan, M.; Rivier, J.; Walker, C.; Abogadie, F.C.; Yoshikami, D.; Cruz, L.J.; Olivera, B.M. Novel excitatory Conus peptides define a new conotoxin superfamily. J. Neurochem. 2003, 85, 610-621. [CrossRef]

15. Terlau, H.; Shon, K.J.; Grilley, M.; Stocker, M.; Stuhmer, W.; Olivera, B.M. Strategy for rapid immobilization of prey by a fish-hunting marine snail. Nature 1996, 381, 148-151. [CrossRef] [PubMed]

16. Cruz, L.J.; Gray, W.R.; Olivera, B.M.; Zeikus, R.D.; Kerr, L.; Yoshikami, D.; Moczydlowski, E. Conus geographus toxins that discriminate between neuronal and muscle sodium channels. J. Biol. Chem. 1985, 260, 9280-9288.

17. Sharpe, I.A.; Gehrmann, J.; Loughnan, M.L.; Thomas, L.; Adams, D.A.; Atkins, A.; Palant, E.; Craik, D.J.; Adams, D.J.; Alewood, P.F.; et al. Two new classes of conopeptides inhibit the alpha 1-adrenoceptor and noradrenaline transporter. Nat. Neurosci. 2001, 4, 902-907. [CrossRef] [PubMed]

18. England, L.J.; Gulyas, J. Inactivation of a serotonin-gated ion channel by a polypeptide toxin from marine snails (vol 281, pg 575, 1998). Science 1998, 282, 417.

19. Petrel, C.; Hocking, H.G.; Reynaud, M.; Upert, G.; Favreau, P.; Biass, D.; Paolini-Bertrand, M.; Peigneur, S.; Tytgat, J.; Gilles, N.; et al. Identification, structural and pharmacological characterization of $\tau$-CnVA, a conopeptide that selectively interacts with somatostatin sst3 receptor. Biochem. Pharmacol. 2013, 85, 1663-1671. [CrossRef]

20. Olivera, B.M.; McIntosh, J.M.; Cruz, L.J.; Luque, F.A.; Gray, W.R. Purification and sequence of a presynaptic peptide toxin from Conus geographus venom. Biochemistry 1984, 23, 5087-5090. [CrossRef] [PubMed]

21. Jin, A.H.; Dekan, Z.; Smout, M.J.; Wilson, D.; Dutertre, S.; Vetter, I.; Lewis, R.J.; Loukas, A.; Daly, N.L.; Alewood, P.F. Conotoxin $\Phi$-MiXXVIIA from the Superfamily G2 Employs a Novel Cysteine Framework that Mimics Granulin and Displays Anti-Apoptotic Activity. Angew. Chem. 2017, 56, 14973-14976. [CrossRef]

22. Olivera, B.M.; McIntosh, J.M.; Clark, C.; Middlemas, D.; Gray, W.R.; Cruz, L.J. A sleep-inducing peptide from Conus geographus venom. Toxicon 1985, 23, 277-282. [CrossRef]

23. Safavi-Hemami, H.; Gajewiak, J.; Karanth, S.; Robinson, S.D.; Ueberheide, B.; Douglass, A.D.; Schlegel, A.; Imperial, J.S.; Watkins, M.; Bandyopadhyay, P.K.; et al. Specialized insulin is used for chemical warfare by fish-hunting cone snails. Proc. Natl. Acad. Sci. USA 2015, 112, 1743-1748. [CrossRef]

24. Cruz, L.J.; de Santos, V.; Zafaralla, G.C.; Ramilo, C.A.; Zeikus, R.; Gray, W.R.; Olivera, B.M. Invertebrate vasopressin/oxytocin homologs. Characterization of peptides from Conus geographus and Conus striatus venoms. J. Biol. Chem. 1987, 262, 15821-15824.

25. Clark, C.; Olivera, B.M.; Cruz, L.J. A toxin from the venom of the marine snail Conus geographus which acts on the vertebrate central nervous system. Toxicon 1981, 19, 691-699. [CrossRef]

26. McIntosh, M.; Cruz, L.J.; Hunkapiller, M.W.; Gray, W.R.; Olivera, B.M. Isolation and structure of a peptide toxin from the marine snail Conus magus. Arch. Biochem. Biophys. 1982, 218, 329-334. [CrossRef]

27. Gray, W.R.; Luque, A.; Olivera, B.M.; Barrett, J.; Cruz, L.J. Peptide toxins from Conus geographus venom. J. Biochem. 1981, 256, 4734-4740.

28. Feldman, D.H.; Olivera, B.M.; Yoshikami, D. Omega Conus geographus toxin-A peptide that blocks calcium channels. FEBS Lett. 1987, 214, 295-300. [CrossRef]

29. Craig, A.G.; Zafaralla, G.; Cruz, L.J.; Santos, A.D.; Hillyard, D.R.; Dykert, J.; Rivier, J.E.; Gray, W.R.; Imperial, J.; DelaCruz, R.G.; et al. An O-glycosylated neuroexcitatory Conus peptide. Biochemistry 1989, 37, 16019-16025. [CrossRef] 
30. Cruz, L.J.; Kupryszewski, G.; LeCheminant, G.W.; Gray, W.R.; Olivera, B.M.; Rivier, J. Mu-conotoxin GIIIA, a peptide ligand for muscle sodium channels: Chemical synthesis, radiolabeling, and receptor characterization. Biochemistry 1989, 28, 3437-3442. [CrossRef]

31. Rybin, M.J.; O’Brien, H.; Ramiro, I.B.L.; Azam, L.; McIntosh, J.M.; Olivera, B.M.; Safavi-Hemami, H.; Yoshikami, D. $\alpha$ M-Conotoxin MIIIJ Blocks Nicotinic Acetylcholine Receptors at Neuromuscular Junctions of Frog and Fish. Toxins 2020, 12, 197. [CrossRef]

32. Olivera, B.M.; Seger, J.; Horvath, M.P.; Fedosov, A.E. Prey-Capture Strategies of Fish-Hunting Cone Snails: Behavior, Neurobiology and Evolution. Brain Behav. Evol. 2015, 86, 58-74. [CrossRef]

33. Robinson, S.D.; Norton, R.S. Conotoxin gene superfamilies. Mar. Drugs 2014, 12, 6058-6101. [CrossRef]

34. Li, Q.; Watkins, M.; Robinson, S.D.; Safavi-Hemami, H.; Yandell, M. Discovery of Novel Conotoxin Candidates Using Machine Learning. Toxins 2018, 10, 503. [CrossRef]

35. Safavi-Hemami, H.; Brogan, S.E.; Olivera, B.M. Pain therapeutics from cone snail venoms: From Ziconotide to novel non-opioid pathways. J. Proteom. 2019, 190, 12-20. [CrossRef] [PubMed]

36. Kerr, L.M.; Yoshikami, D. A venom peptide with a novel presynaptic blocking action. Nature 1984, 308, 282-284. [CrossRef] [PubMed]

37. McCleskey, E.W.; Fox, A.P.; Feldman, D.H.; Cruz, L.J.; Olivera, B.M.; Tsien, R.W.; Yoshikami, D. Omega-conotoxin: Direct and persistent blockade of specific types of calcium channels in neurons but not muscle. Proc. Natl. Acad. Sci. USA 1987, 84, 4327-4331. [CrossRef]

38. Todd, A.J. Neuronal circuitry for pain processing in the dorsal horn. Nat. Rev. Neurosci. 2010, 11, 823-836. [CrossRef] [PubMed]

39. Miljanich, G.P. Ziconotide: Neuronal calcium channel blocker for treating severe chronic pain. Curr. Med. Chem. 2004, 11, 3029-3040. [CrossRef] [PubMed]

40. Deer, T.R.; Pope, J.E.; Hayek, S.M.; Bux, A.; Buchser, E.; Eldabe, S.; De Andrés, J.A.; Erdek, M.; Patin, D.; Grider, J.S.; et al. The Polyanalgesic Consensus Conference (PACC): Recommendations on Intrathecal Drug Infusion Systems Best Practices and Guidelines. Neuromodulation J. Int. Neuromodulation Soc. 2017, 20, 96-132. [CrossRef]

41. Webster, L.R. The Relationship Between the Mechanisms of Action and Safety Profiles of Intrathecal Morphine and Ziconotide: A Review of the Literature. Pain Med. 2015, 16, 1265-1277. [CrossRef]

42. Pennington, M.W.; Czerwinski, A.; Norton, R.S. Peptide therapeutics from venom: Current status and potential. Bioorg. Med. Chem. 2018, 26, 2738-2758. [CrossRef]

43. King, G.F. Venoms as a platform for human drugs: Translating toxins into therapeutics. Expert Opin. Biol. Ther. 2011, 11, 1469-1484. [CrossRef]

44. Robinson, S.D.; Safavi-Hemami, H. Venom peptides as pharmacological tools and therapeutics for diabetes. Neuropharmacology 2017. [CrossRef]

45. Sher, E.; Gotti, C.; Canal, N.; Scoppetta, C.; Piccolo, G.; Evoli, A.; Clementi, F. Specificity of calcium channel autoantibodies in Lambert-Eaton myasthenic syndrome. Lancet 1989, 2, 640-643. [CrossRef]

46. Lennon, V.A.; Kryzer, T.J.; Griesmann, G.E.; O'Suilleabhain, P.E.; Windebank, A.J.; Woppmann, A.; Miljanich, G.P.; Lambert, E.H. Calcium-channel antibodies in the Lambert-Eaton syndrome and other paraneoplastic syndromes. N. Engl. J. Med. 1995, 332, 1467-1474. [CrossRef]

47. Mareska, M.; Gutmann, L. Lambert-Eaton myasthenic syndrome. Semin. Neurol. 2004, 24, 149-153. [CrossRef] [PubMed]

48. Leys, K.; Lang, B.; Johnston, I.; Newsom-Davis, J. Calcium channel autoantibodies in the Lambert-Eaton myasthenic syndrome. Ann. Neurol. 1991, 29, 307-314. [CrossRef] [PubMed]

49. Motomura, M.; Johnston, I.; Lang, B.; Vincent, A.; Newsom-Davis, J. An improved diagnostic assay for Lambert-Eaton myasthenic syndrome. J. Neurol. Neurosurg. Psychiatry 1995, 58, 85-87. [CrossRef]

50. Lang, B.; Waterman, S.; Pinto, A.; Jones, D.; Moss, F.; Boot, J.; Brust, P.; Williams, M.; Stauderman, K.; Harpold, M.; et al. The role of autoantibodies in Lambert-Eaton myasthenic syndrome. Ann. N. Y. Acad. Sci. 1998, 841, 596-605. [CrossRef]

51. Skeie, G.O.; Apostolski, S.; Evoli, A.; Gilhus, N.E.; Illa, I.; Harms, L.; Hilton-Jones, D.; Melms, A.; Verschuuren, J.; Horge, H.W. Guidelines for treatment of autoimmune neuromuscular transmission disorders. Eur. J. Neurol. 2010, 17, 893-902. [CrossRef] 
52. Favreau, P.; Benoit, E.; Hocking, H.G.; Carlier, L.; D' hoedt, D.; Leipold, E.; Markgraf, R.; Schlumberger, S.; Córdova, M.A.; Gaertner, H.; et al. A novel $\mu$-conopeptide, CnIIIC, exerts potent and preferential inhibition of NaV1.2/1.4 channels and blocks neuronal nicotinic acetylcholine receptors. Br. J. Pharmacol. 2012, 166, 1654-1668. [CrossRef]

53. Westenbroek, R.E.; Hell, J.W.; Warner, C.; Dubel, S.J.; Snutch, T.P.; Catterall, W.A. Biochemical properties and subcellular distribution of an N-type calcium channel alpha 1 subunit. Neuron 1992, 9, 1099-1115. [CrossRef]

54. Hayashi, K.; Wakino, S.; Sugano, N.; Ozawa, Y.; Homma, K.; Saruta, T. Ca2+ channel subtypes and pharmacology in the kidney. Circ. Res. 2007, 100, 342-353. [CrossRef]

55. Li, D.; Paterson, D.J. Pre-synaptic sympathetic calcium channels, cyclic nucleotide-coupled phosphodiesterases and cardiac excitability. Semin. Cell Dev. Biol. 2019, 94, 20-27. [CrossRef] [PubMed]

56. Ellison, M.; McIntosh, J.M.; Olivera, B.M. Alpha-conotoxins ImI and ImII. Similar alpha 7 nicotinic receptor antagonists act at different sites. J. Biol. Chem. 2003, 278, 757-764. [CrossRef] [PubMed]

57. Broxton, N.M.; Down, J.G.; Gehrmann, J.; Alewood, P.F.; Satchell, D.G.; Livett, B.G. Alpha-conotoxin ImI inhibits the alpha-bungarotoxin-resistant nicotinic response in bovine adrenal chromaffin cells. J. Neurochem. 1999, 72, 1656-1662. [CrossRef] [PubMed]

58. Terlau, H.; Olivera, B.M. Conus Venoms: A Rich Source of Novel Ion Channel-Targeted Peptides. Physiol. Rev. 2004, 84, 41-68. [CrossRef]

59. Azam, L.; McIntosh, J.M. Alpha-conotoxins as pharmacological probes of nicotinic acetylcholine receptors. Acta Pharmacol. Sin. 2009, 30, 771-783. [CrossRef]

60. Giribaldi, J.; Dutertre, S. $\alpha$-Conotoxins to explore the molecular, physiological and pathophysiological functions of neuronal nicotinic acetylcholine receptors. Neurosci. Lett. 2018, 679, 24-34. [CrossRef]

61. Heghinian, M.D.; Mejia, M.; Adams, D.J.; Godenschwege, T.A.; Marí, F. Inhibition of cholinergic pathways in Drosophila melanogaster by $\alpha$-conotoxins. FASEB J. Off. Publ. Fed. Am. Soc. Exp. Biol. 2015, 29, 1011-1018. [CrossRef]

62. Mei, D.; Lin, Z.; Fu, J.; He, B.; Gao, W.; Ma, L.; Dai, W.; Zhang, H.; Wang, X.; Wang, J.; et al. The use of $\alpha$-conotoxin ImI to actualize the targeted delivery of paclitaxel micelles to $\alpha 7 \mathrm{nAChR}$-overexpressing breast cancer. Biomaterials 2015, 42, 52-65. [CrossRef]

63. Walker, C.S.; Jensen, S.; Ellison, M.; Matta, J.A.; Lee, W.Y.; Imperial, J.S.; Duclos, N.; Brockie, P.J.; Madsen, D.M.; Isaac, J.T.R.; et al. A Novel Conus Snail Polypeptide Causes Excitotoxicity by Blocking Desensitization of AMPA Receptors. Curr. Biol. 2009, 19, 900-908. [CrossRef]

64. Chen, L.; Durr, K.L.; Gouaux, E. X-ray structures of AMPA receptor-cone snail toxin complexes illuminate activation mechanism. Science 2014, 345, 1021-1026. [CrossRef]

65. Menting, J.G.; Gajewiak, J.; MacRaild, C.A.; Chou, D.H.; Disotuar, M.M.; Smith, N.A.; Miller, C.; Erchegyi, J.; Rivier, J.E.; Olivera, B.M.; et al. A minimized human insulin-receptor-binding motif revealed in a Conus geographus venom insulin. Nat. Struct. Mol. Biol. 2016, 23, 916-920. [CrossRef] [PubMed]

66. Buczek, O.; Olivera, B.M.; Bulaj, G. Propeptide Does Not Act as an Intramolecular Chaperone but Facilitates Protein Disulfide Isomerase-Assisted Folding of a Conotoxin Precursor. Biochemistry 2004, 43, 1093-1101. [CrossRef] [PubMed]

67. Safavi-Hemami, H.; Bulaj, G.; Olivera, B.M.; Williamson, N.A.; Purcell, A.W. Identification of Conus peptidylprolyl cis-trans isomerases (PPIases) and assessment of their role in the oxidative folding of conotoxins. J. Biol. Chem. 2010, 285, 12735-12746. [CrossRef] [PubMed]

68. Safavi-Hemami, H.; Li, Q.; Jackson, R.L.; Song, A.S.; Boomsma, W.; Bandyopadhyay, P.K.; Gruber, C.W.; Purcell, A.W.; Yandell, M.; Olivera, B.M.; et al. Rapid expansion of the protein disulfide isomerase gene family facilitates the folding of venom peptides. Proc. Natl. Acad. Sci. USA 2016, 113, 3227-3232. [CrossRef] [PubMed]

69. Fuller, E.; Green, B.R.; Catlin, P.; Buczek, O.; Nielsen, J.S.; Olivera, B.M.; Bulaj, G. Oxidative folding of conotoxins sharing an identical disulfide bridging framework. FEBS J. 2005, 272, 1727-1738. [CrossRef] [PubMed]

70. Bandyopadhyay, P.K.; Colledge, C.J.; Walker, C.S.; Zhou, L.-M.; Hillyard, D.R.; Olivera, B.M. Conantokin-G Precursor and Its Role in g-Carboxylation by a Vitamin K-dependent Carboxylase from a Conus Snail. J. Biol. Chem. 1998, 273, 5447-5450. [CrossRef] 
71. Bulaj, G.; Buczek, O.; Goodsell, I.; Jimenez, E.C.; Kranski, J.; Nielsen, J.S.; Garrett, J.E.; Olivera, B.M. Efficient oxidative folding of conotoxins and the radiation of venomous cone snails. Proc. Natl. Acad. Sci. USA 2003, 100, 14562-14568. [CrossRef]

72. Safavi-Hemami, H.; Lu, A.; Li, Q.; Fedosov, A.E.; Biggs, J.; Showers Corneli, P.; Seger, J.; Yandell, M.; Olivera, B.M. Venom Insulins of Cone Snails Diversify Rapidly and Track Prey Taxa. Mol. Biol. Evol. 2016, 33, 2924-2934. [CrossRef]

73. Chang, D.; Duda, T.F., Jr. Age-related association of venom gene expression and diet of predatory gastropods. BMC Evol. Biol. 2016, 16, 27. [CrossRef]

74. Duda, T.F.; Palumbi, S.R. Gene expression and feeding ecology: Evolution of piscivory in the venomous gastropod genus Conus. Proc. R. Soc. Lond. Ser. B-Biol. Sci. 2004, 271, 1165-1174. [CrossRef]

75. Phuong, M.A.; Mahardika, G.N. Targeted sequencing of venom genes from cone snail genomes reveals coupling between dietary breadth and conotoxin diversity. bioRxiv 2017. [CrossRef]

76. Phuong, M.A.; Mahardika, G.N.; Alfaro, M.E. Dietary breadth is positively correlated with venom complexity in cone snails. BMC Genom. 2016, 17, 401. [CrossRef] [PubMed]

77. Chang, D.; Duda, T.F.J. Extensive and continuous duplication facilitates rapid evolution and diversification of gene families. Mol. Biol. Evol. 2012, 29, 2019-2029. [CrossRef] [PubMed]

78. Duda, T.F.; Palumbi, S.R. Molecular genetics of ecological diversification: Duplication and rapid evolution of toxin genes of the venomous gastropod Conus. Proc. Natl. Acad. Sci. USA 1999, 96, 6820-6823. [CrossRef] [PubMed]

79. Puillandre, N.; Watkins, M.; Olivera, B.M. Evolution of Conus peptide genes: Duplication and positive selection in the A-superfamily. J. Mol. Evol. 2010, 70, 190-202. [CrossRef]

80. Cartier, G.E.; Yoshikami, D.; Gray, W.R.; Luo, S.; Olivera, B.M.; McIntosh, J.M. A New a-Conotoxin Which Targets $\alpha 3 \beta 2$ Nicotinic Acetylcholine Receptors. J. Biol. Chem. 1996, 271, 7522-7528. [CrossRef]

81. Safronova, V.G.; Vulfius, C.A.; Shelukhina, I.V.; Mal'tseva, V.N.; Berezhnov, A.V.; Fedotova, E.I.; Miftahova, R.G.; Kryukova, E.V.; Grinevich, A.A.; Tsetlin, V.I. Nicotinic receptor involvement in regulation of functions of mouse neutrophils from inflammatory site. Immunobiology 2016, 221, 761-772. [CrossRef]

82. Sanjakdar, S.S.; Maldoon, P.P.; Marks, M.J.; Brunzell, D.H.; Maskos, U.; McIntosh, J.M.; Bowers, M.S.; Damaj, M.I. Differential roles of $\alpha 6 \beta 2^{*}$ and $\alpha 4 \beta 2^{*}$ neuronal nicotinic receptors in nicotine- and cocaine-conditioned reward in mice. Neuropsychopharmacol. Off. Publ. Am. Coll. Neuropsychopharmacol. 2015, 40, 350-360. [CrossRef]

83. Zhao-Shea, R.; Liu, L.; Soll, L.G.; Improgo, M.R.; Meyers, E.E.; McIntosh, J.M.; Grady, S.R.; Marks, M.J.; Gardner, P.D.; Tapper, A.R. Nicotine-mediated activation of dopaminergic neurons in distinct regions of the ventral tegmental area. Neuropsychopharmacol. Off. Publ. Am. Coll. Neuropsychopharmacol. 2011, 36, 1021-1032. [CrossRef]

84. Ellison, M.; Haberlandt, C.; Gomez-Casati, M.E.; Watkins, M.; Elgoyhen, A.B.; McIntosh, J.M.; Olivera, B.M. Alpha-RgIA: A novel conotoxin that specifically and potently blocks the alpha9alpha10 nAChR. Biochemistry 2006, 45, 1511-1517. [CrossRef]

85. Vincler, M.; Wittenauer, S.; Parker, R.; Ellison, M.; Olivera, B.M.; McIntosh, J.M. Molecular mechanism for analgesia involving specific antagonism of alpha9alpha10 nicotinic acetylcholine receptors. Proc. Natl. Acad. Sci. USA 2006, 103, 17880-17884. [CrossRef] [PubMed]

86. Satkunanathan, N.; Livett, B.G.; Gayler, K.; Sandall, D.; Down, J.G.; Khalil, Z. Alpha-conotoxin Vc1.1 alleviates neuropathic pain and accelerates functional recovery of injured neurones. Brain Res. 2005, 1059, 149-158. [CrossRef]

87. McIntosh, J.M.; Absalom, N.; Chebib, M.; Elgoyhen, A.B.; Vincler, M. Alpha9 nicotinic acetylcholine receptors and the treatment of pain. Biochem. Pharmacol. 2009, 78, 693-702. [CrossRef] [PubMed]

88. Di Cesare Mannelli, L.; Cinci, L.; Micheli, L.; Zanardelli, M.; Pacini, A.; McIntosh, J.M.; Ghelardini, C. Alpha-conotoxin RgIA protects against the development of nerve injury-induced chronic pain and prevents both neuronal and glial derangement. Pain 2014, 155, 1986-1995. [CrossRef] [PubMed]

89. Richter, K.; Sagawe, S.; Hecker, A.; Küllmar, M.; Askevold, I.; Damm, J.; Heldmann, S.; Pöhlmann, M.; Ruhrmann, S.; Sander, M.; et al. C-Reactive Protein Stimulates Nicotinic Acetylcholine Receptors to Control ATP-Mediated Monocytic Inflammasome Activation. Front. Immunol. 2018, 9, 1604. [CrossRef] 
90. Richter, K.; Koch, C.; Perniss, A.; Wolf, P.M.; Schweda, E.K.H.; Wichmann, S.; Wilker, S.; Magel, I.; Sander, M.; McIntosh, J.M.; et al. Phosphocholine-Modified Lipooligosaccharides of Haemophilus influenzae Inhibit ATP-Induced IL-1 $\beta$ Release by Pulmonary Epithelial Cells. Molecules 2018, 23, 1979. [CrossRef]

91. Grau, V.; Richter, K.; Hone, A.J.; McIntosh, J.M. Conopeptides [V11L;V16D] ArIB and RgIA4: Powerful Tools for the Identification of Novel Nicotinic Acetylcholine Receptors in Monocytes. Front. Pharmacol. 2018, 9 , 1499. [CrossRef]

92. Xiong, X.; Menting, J.; Disotuar, M.; Smith, N.; Delanie, C.; Ghabash, G.; Agrawal, R.; Wang, X.; He, X.; Fisher, S.; et al. A structurally minimized insulin based on cone-snail venom insulin principles. Nat. Struct. Mol. Biol. 2020, 27, 615-624. [CrossRef]

93. Dave, K.; Lahiry, A. Conotoxins: Review and docking studies to determine potentials of conotoxin as an anticancer drug molecule. Curr. Top. Med. Chem. 2012, 12, 845-851. [CrossRef]

94. Lubbers, N.L.; Campbell, T.J.; Polakowski, J.S.; Bulaj, G.; Layer, R.T.; Moore, J.; Gross, G.J.; Cox, B.F. Postischemic administration of CGX-1051, a peptide from cone snail venom, reduces infarct size in both rat and dog models of myocardial ischemia and reperfusion. J. Cardiovasc. Pharmacol. 2005, 46, 141-146. [CrossRef]

95. Chen, P.; Dendorfer, A.; Finol-Urdaneta, R.K.; Terlau, H.; Olivera, B.M. Biochemical characterization of kappaM-RIIIJ, a Kv1.2 channel blocker: Evaluation of cardioprotective effects of kappaM-conotoxins. J. Biol. Chem. 2010, 285, 14882-14889. [CrossRef] [PubMed]

96. Cordeiro, S.; Finol-Urdaneta, R.K.; Köpfer, D.; Markushina, A.; Song, J.; French, R.J.; Kopec, W.; de Groot, B.L.; Giacobassi, M.J.; Leavitt, L.S.; et al. Conotoxin kM-RIIIJ, a tool targeting asymmetric heteromeric K(v)1 channels. Proc. Natl. Acad. Sci. USA 2019, 116, 1059-1064. [CrossRef] [PubMed]

97. Teichert, R.W.; Raghuraman, S.; Memon, T.; Cox, J.L.; Foulkes, T.; Rivier, J.E.; Olivera, B.M. Characterization of two neuronal subclasses through constellation pharmacology. Proc. Natl. Acad. Sci. USA 2012, 109, 12758-12763. [CrossRef]

98. Teichert, R.W.; Smith, N.J.; Raghuraman, S.; Yoshikami, D.; Light, A.R.; Olivera, B.M. Functional profiling of neurons through cellular neuropharmacology. Proc. Natl. Acad. Sci. USA 2012, 109, 1388-1395. [CrossRef] [PubMed]

99. Coleman, S.K.; Newcombe, J.; Pryke, J.; Dolly, J.O. Subunit composition of Kv1 channels in human CNS. J. Neurochem. 1999, 73, 849-858. [CrossRef]

100. Huang, R.; Wang, Y.; Li, J.; Jiang, X.; Li, Y.; Liu, B.; Wu, X.; Du, X.; Hang, Y.; Jin, M.; et al. Ca(2+)-independent but voltage-dependent quantal catecholamine secretion (CiVDS) in the mammalian sympathetic nervous system. Proc. Natl. Acad. Sci. USA 2019, 116, 20201-20209. [CrossRef]

101. Dooley, D.J.; Lupp, A.; Hertting, G.; Osswald, H. Omega-conotoxin GVIA and pharmacological modulation of hippocampal noradrenaline release. Eur. J. Pharmacol. 1988, 148, 261-267. [CrossRef]

102. Hansen, T.; Tarasova, O.S.; Khammy, M.M.; Ferreira, A.; Kennard, J.A.; Andresen, J.; Staehr, C.; Brain, K.L.; Nilsson, H.; Aalkjaer, C. $[\mathrm{Ca}(2+)]$ changes in sympathetic varicosities and Schwann cells in rat mesenteric arteries-Relation to noradrenaline release and contraction. Acta Physiol. 2019, 226, e13279. [CrossRef]

103. Scott, D.A.; Wright, C.E.; Angus, J.A. Actions of intrathecal omega-conotoxins CVID, GVIA, MVIIA, and morphine in acute and neuropathic pain in the rat. Eur. J. Pharmacol. 2002, 451, 279-286. [CrossRef]

104. Nigam, A.; Hargus, N.J.; Barker, B.S.; Ottolini, M.; Hounshell, J.A.; Bertram, E.H., III; Perez-Reyes, E.; Patel, M.K. Inhibition of T-Type calcium channels in mEC layer II stellate neurons reduces neuronal hyperexcitability associated with epilepsy. Epilepsy Res. 2019, 154, 132-138. [CrossRef]

105. Tarif, N.; Bakris, G.L. Preservation of renal function: The spectrum of effects by calcium-channel blockers. Nephrol. Dial. Transplant. 1997, 12, 2244-2250. [CrossRef] [PubMed]

106. Dolmetsch, R.E.; Pajvani, U.; Fife, K.; Spotts, J.M.; Greenberg, M.E. Signaling to the nucleus by an L-type calcium channel-calmodulin complex through the MAP kinase pathway. Science 2001, 294, 333-339. [CrossRef] [PubMed]

107. Hillyard, D.R.; Monje, V.D.; Mintz, I.M.; Bean, B.P.; Nadasdi, L.; Ramachandran, J.; Miljanich, G.; Azimi-Zoonooz, A.; McIntosh, J.M.; Cruz, L.J.; et al. A new Conus peptide ligand for mammalian presynaptic Ca2+ channels. Neuron 1992, 9, 69-77. [CrossRef]

108. McDonough, S.I.; Swartz, K.J.; Mintz, I.M.; Boland, L.M.; Bean, B.P. Inhibition of calcium channels in rat central and peripheral neurons by omega-conotoxin MVIIC. J. Neurosci. Off. J. Soc. Neurosci. 1996, 16, 2612-2623. [CrossRef] 
109. Tian, G.F.; Azmi, H.; Takano, T.; Xu, Q.; Peng, W.; Lin, J.; Oberheim, N.; Lou, N.; Wang, X.; Zielke, H.R.; et al. An astrocytic basis of epilepsy. Nat. Med. 2005, 11, 973-981. [CrossRef]

110. Carter, B.C.; Jahr, C.E. Postsynaptic, not presynaptic NMDA receptors are required for spike-timing-dependent LTD induction. Nat. Neurosci. 2016, 19, 1218-1224. [CrossRef] [PubMed]

111. Zhang, Y.; Qin, W.; Qian, Z.; Liu, X.; Wang, H.; Gong, S.; Sun, Y.G.; Snutch, T.P.; Jiang, X.; Tao, J. Peripheral pain is enhanced by insulin-like growth factor 1 through a $G$ protein-mediated stimulation of T-type calcium channels. Sci. Signal. 2014, 7, ra94. [CrossRef]

112. Wang, H.; Wei, Y.; Pu, Y.; Jiang, D.; Jiang, X.; Zhang, Y.; Tao, J. Brain-derived neurotrophic factor stimulation of T-type $\mathrm{Ca}(2+)$ channels in sensory neurons contributes to increased peripheral pain sensitivity. Sci. Signal. 2019, 12. [CrossRef]

113. Phuong, M.A.; Mahardika, G.N. Targeted Sequencing of Venom Genes from Cone Snail Genomes Improves Understanding of Conotoxin Molecular Evolution. Mol. Biol. Evol. 2018, 35, 1210-1224. [CrossRef]

114. Turchetto, J.; Sequeira, A.F.; Ramond, L.; Peysson, F.; Bras, J.L.; Saez, N.J.; Duhoo, Y.; Blemont, M.; Guerreiro, C.I.; Quinton, L.; et al. High-throughput expression of animal venom toxins in Escherichia coli to generate a large library of oxidized disulphide-reticulated peptides for drug discovery. Microb. Cell Factories 2017, 16, 6. [CrossRef]

115. Sequeira, A.F.; Turchetto, J.; Saez, N.J.; Peysson, F.; Ramond, L.; Duhoo, Y.; Blémont, M.; Fernandes, V.O.; Gama, L.T.; Ferreira, L.M.; et al. Gene design, fusion technology and TEV cleavage conditions influence the purification of oxidized disulphide-rich venom peptides in Escherichia coli. Microb. Cell Factories 2017, 16, 4. [CrossRef] [PubMed]

116. Nielsen, L.D.; Foged, M.M.; Albert, A.; Bertelsen, A.B.; Soltoft, C.L.; Robinson, S.D.; Petersen, S.V.; Purcell, A.W.; Olivera, B.M.; Norton, R.S.; et al. The three-dimensional structure of an H-superfamily conotoxin reveals a granulin fold arising from a common ICK cysteine framework. J. Biol. Chem. 2019, 294, 8745-8759. [CrossRef] [PubMed]

117. Teichert, R.W.; Memon, T.; Aman, J.W.; Olivera, B.M. Using constellation pharmacology to define comprehensively a somatosensory neuronal subclass. Proc. Natl. Acad. Sci. USA 2014, 111, 2319-2324. [CrossRef] [PubMed]

118. MacRae, C.A.; Peterson, R.T. Zebrafish as tools for drug discovery. Nat. Rev. Drug Discov. 2015, 14, 721-731. [CrossRef]

119. Tay, B.; Stewart, T.A.; Davis, F.M.; Deuis, J.R.; Vetter, I. Development of a high-throughput fluorescent no-wash sodium influx assay. PLoS ONE 2019, 14, e0213751. [CrossRef]

120. Fosgerau, K.; Hoffmann, T. Peptide therapeutics: Current status and future directions. Drug Discov. Today 2015, 20, 122-128. [CrossRef]

121. Kohn, A.J. Conus Envenomation of Humans: In Fact and Fiction. Toxins 2018, 11, 10. [CrossRef]

122. Kizer, K.W. Marine envenomations. J. Toxicol. Clin. Toxicol. 1983, 21, 527-555. [CrossRef]

123. McIntosh, J.M.; Jones, R.M. Cone venom-from accidental stings to deliberate injection. Toxicon 2001, 39, 1447-1451. [CrossRef]

124. Halford, Z.A.; Yu, P.Y.; Likeman, R.K.; Hawley-Molloy, J.S.; Thomas, C.; Bingham, J.P. Cone shell envenomation: Epidemiology, pharmacology and medical care. Diving Hyperb. Med. 2015, 45, $200-207$.

125. World Health Organization Snakebite Report. Available online: https://www.who.int/snakebites/disease/en/ (accessed on 14 July 2020).

126. Chippaux, J.P.; Goyffon, M. Epidemiology of scorpionism: A global appraisal. Acta Trop. 2008, 107, 71-79. [CrossRef] [PubMed]

127. Kularatne, S.A.; Dinamithra, N.P.; Sivansuthan, S.; Weerakoon, K.G.; Thillaimpalam, B.; Kalyanasundram, V.; Ranawana, K.B. Clinico-epidemiology of stings and envenoming of Hottentotta tamulus (Scorpiones: Buthidae), the Indian red scorpion from Jaffna Peninsula in northern Sri Lanka. Toxicon 2015, 93, 85-89. [CrossRef] [PubMed]

128. Rodrigo, C.; Gnanathasan, A. Management of scorpion envenoming: A systematic review and meta-analysis of controlled clinical trials. Syst. Rev. 2017, 6, 74. [CrossRef] [PubMed]

129. Slagboom, J.; Kool, J.; Harrison, R.A.; Casewell, N.R. Haemotoxic snake venoms: Their functional activity, impact on snakebite victims and pharmaceutical promise. Br. J. Haematol. 2017, 177, 947-959. [CrossRef] [PubMed] 
130. Saab, F.; Ionescu, C.; Schweiger, M.J. Bleeding risk and safety profile related to the use of eptifibatide: A current review. Expert Opin. Drug Saf. 2012, 11, 315-324. [CrossRef] [PubMed]

131. Serrano, S.M. The long road of research on snake venom serine proteinases. Toxicon 2013, 62, 19-26. [CrossRef]

132. Ortiz, E.; Gurrola, G.B.; Schwartz, E.F.; Possani, L.D. Scorpion venom components as potential candidates for drug development. Toxicon 2015, 93, 125-135. [CrossRef]

133. Tenorio, M.J. Conotoxins: Weapons of Mass Destruction? Cone Collect. 2013, 22, 6-7.

134. McManus, O.B.; Musick, J.R.; Gonzalez, C. Peptides isolated from the venom of Conus geographus block neuromuscular transmission. Neurosci. Lett. 1981, 25, 57-62. [CrossRef]

135. McManus, O.B.; Musick, J.R. Postsynaptic block of frog neuromuscular transmission by conotoxin GI. J. Neurosci. Off. J. Soc. Neurosci. 1985, 5, 110-116. [CrossRef]

136. Groebe, D.R.; Gray, W.R.; Abramson, S.N. Determinants involved in the affinity of alpha-conotoxins GI and SI for the muscle subtype of nicotinic acetylcholine receptors. Biochemistry 1997, 36, 6469-6474. [CrossRef]

137. Almquist, R.G.; Kadambi, S.R.; Yasuda, D.M.; Weitl, F.L.; Polgar, W.E.; Toll, L.R. Paralytic activity of (des-Glu1)conotoxin GI analogs in the mouse diaphragm. Int. J. Pept. Protein Res. 1989, 34, 455-462. [CrossRef] [PubMed]

138. Ahorukomeye, P.; Disotuar, M.M.; Gajewiak, G.; Karanth, S.; Watkins, M.; Robinson, S.D.; Flórez Salcedo, P.; Smith, N.A.; Smith, B.J.; Schlegel, A.; et al. Fish-hunting cone snail venoms are a rich source of minimized ligands of the vertebrate insulin receptor. eLife 2019, 8, e41574. [CrossRef] [PubMed]

139. McIntosh, J.M.; Dowell, C.; Watkins, M.; Garrett, J.E.; Yoshikami, D.; Olivera, B.M. A-Conotoxin GIC from Conus geographus, a Novel Peptide Antagonist of Nicotinic Acetylcholine Receptors. J. Biol. Chem. 2002, 277, 33610-33615. [CrossRef] [PubMed]

140. Clark, R.J.; Jensen, J.E.; Nevin, S.T.; Callaghan, B.P.; Adams, D.J.; Craik, D.J. The engineering of an orally active conotoxin for the treatment of neuropathic pain. Angew. Chem. 2010, 49, 6545-6548. [CrossRef] [PubMed]

141. Suszkiw, J.B.; Murawsky, M.M.; Shi, M. Further characterization of phasic calcium influx in rat cerebrocortical synaptosomes: Inferences regarding calcium channel type(s) in nerve endings. J. Neurochem. 1989, 52, 1260-1269. [CrossRef]

142. Xiao, H.; Pan, H.; Liao, K.; Yang, M.; Huang, C. Snake Venom PLA(2), a Promising Target for Broad-Spectrum Antivenom Drug Development. BioMed Res. Int. 2017, 2017, 6592820. [CrossRef] [PubMed]

143. Stirpe, F.; Barbieri, L.; Abbondanza, A.; Falasca, A.I.; Brown, A.N.; Sandvig, K.; Olsnes, S.; Pihl, A. Properties of volkensin, a toxic lectin from Adenia volkensii. J. Biol. Chem. 1985, 260, 14589-14595.

144. Lewis, R.J.; Sellin, M.; Poli, M.A.; Norton, R.S.; MacLeod, J.K.; Sheil, M.M. Purification and characterization of ciguatoxins from moray eel (Lycodontis javanicus, Muraenidae). Toxicon 1991, 29, 1115-1127. [CrossRef]

145. Yokoyama, A.; Murata, M.; Oshima, Y.; Iwashita, T.; Yasumoto, T. Some chemical properties of maitotoxin, a putative calcium channel agonist isolated from a marine dinoflagellate. J. Biochem. 1988, 104, 184-187. [CrossRef]

146. Moore, R.E.; Scheuer, P.J. Palytoxin: A new marine toxin from a coelenterate. Science 1971, 172, $495-498$. [CrossRef] [PubMed]

147. Tokuyama, T.; Daly, J.; Witkop, B.; Karle, I.L.; Karle, J. The structure of batrachotoxinin A, a nol vesteroidal alkaloid from the Colombian arrow poison frog, Phyllobates aurotaenia. J. Am. Chem. Soc. 1968, 90, 1917-1918. [CrossRef] [PubMed]

148. Halstead, B.W.; Schantz, E.J.; World Health Organization. Paralytic Shellfish Poisoning; World Health Organization: Geneva, Switzerland, 1984; Volume 79, ISBN 9241700793.

149. Stonik, V.A.; Stonik, I.V. Studies on marine toxins: Chemical and biological aspects. Stud. Mar. Toxins Chem. Biol. Asp. 2010, 79, 5. [CrossRef]

150. Cohen, J.A.; Guardia III, C.F.; Mowchun, J.J.; Stommel, E.W. Demyelinating Diseases of the Peripheral Nerves. In Nerves and Nerve Injuries; Academic Press: Cambridge, MA, USA, 2015; pp. 895-934. [CrossRef]

151. Jones, R.G.; Lee, L.; Landon, J. The effects of specific antibody fragments on the 'irreversible' neurotoxicity induced by Brown snake (Pseudonaja) venom. Br. J. Pharmacol. 1999, 126, 581-584. [CrossRef] [PubMed]

152. Tyler, M.I.; Barnett, D.; Nicholson, P.; Spence, I.; Howden, M.E. Studies on the subunit structure of textilotoxin, a potent neurotoxin from the venom of the Australian common brown snake (Pseudonaja textilis). Biochim. Biophys. Acta 1987, 915, 210-216. [CrossRef] 
153. Benton, B.J.; Keller, S.A.; Spriggs, D.L.; Capacio, B.R.; Chang, F.C. Recovery from the lethal effects of saxitoxin: A therapeutic window for 4-aminopyridine (4-AP). Toxicon 1998, 36, 571-588. [CrossRef]

154. Europa Council Reculation (EC) No 428/2009. Available online: http://data.europa.eu/eli/reg/2009/428/201206-15 (accessed on 14 July 2020).

155. Australian Government Federal Register of Legislation Defence and Strategic Goods List 2019. Available online: https://www.legislation.gov.au/Details/F2019L00424/Html/Text (accessed on 14 July 2020).

156. US Centers for Disease Control and Prevention Select Agents and Toxins List. Available online: https://www.selectagents.gov/SelectAgentsandToxinsList.html (accessed on 14 July 2020).

157. Center for Biosikring og Bioberedskab Liste over Kontrolbelagte Biologiske Stoffer. Available online: https://www.biosikring.dk/681/\#c4878 (accessed on 14 July 2020).

158. The Australia Group. Available online: https://www.dfat.gov.au/publications/minisite/theaustraliagroupnet/ site/en/index.html (accessed on 14 July 2020).

159. Olivera, B.M.; Gray, W.R.; Zeikus, R.; McIntosh, J.M.; Varga, J.; Rivier, J.; Desantos, V.; Cruz, L.J. Peptide neurotoxins from fish-hunting cone snails. Science. 1985, 230, 1338-1343. [CrossRef]

160. Patton, J.S.; Trinchero, P.; Platz, R.M. Bioavailability of pulmonary delivered peptides and proteins: $\alpha$-interferon, calcitonins and parathyroid hormones. In Proceedings of the Sixth International Symposium on Recent Advances in Drug Delivery Systems, Salt Lake City, UT, USA, 21-24 February 1993; pp. 79-85.

161. Adjei, A.; Garren, J. Pulmonary delivery of peptide drugs: Effect of particle size on bioavailability of leuprolide acetate in healthy male volunteers. Pharm. Res. 1990, 7, 565-569. [CrossRef]

162. Agu, R.U.; Ugwoke, M.I.; Armand, M.; Kinget, R.; Verbeke, N. The lung as a route for systemic delivery of therapeutic proteins and peptides. Respir. Res. 2001, 2, 198-209. [CrossRef]

163. Hickey, A.J.; da Rocha, S.R. Pharmaceutical Inhalation Aerosol Technology, 3rd ed.; CRC Press: Boca Raton, FL, USA, 2019; Volume 3, p. 746.

164. Johnson, K.A. Preparation of peptide and protein powders for inhalation. Adv. Drug Deliv. Rev. 1997, 26, 3-15. [CrossRef]

165. Yu, S.; Yang, B.; Yan, L.; Dai, Q. Sensitive Detection of $\alpha$-Conotoxin GI in Human Plasma Using a Solid-Phase Extraction Column and LC-MS/MS. Toxins 2017, 9, 235. [CrossRef] [PubMed]

166. Clark, R.J.; Fischer, H.; Dempster, L.; Daly, N.L.; Rosengren, K.J.; Nevin, S.T.; Meunier, F.A.; Adams, D.J.; Craik, D.J. Engineering stable peptide toxins by means of backbone cyclization: Stabilization of the alpha-conotoxin MII. Proc. Natl. Acad. Sci. USA 2005, 102, 13767-13772. [CrossRef] [PubMed]

167. Di, L. Strategic approaches to optimizing peptide ADME properties. AAPS J. 2015, 17, 134-143. [CrossRef]

168. Smith, M.L.; Vorce, S.P.; Holler, J.M.; Shimomura, E.; Magluilo, J.; Jacobs, A.J.; Huestis, M.A. Modern instrumental methods in forensic toxicology. J. Anal. Toxicol. 2007, 31, 237-253. [CrossRef]

169. Infectious Diseases Society of America. Available online: https://www.idsociety.org (accessed on 6 October 2004).

170. El-Aziz, T.M.A.; Ravelet, C.; Molgo, J.; Fiore, E.; Pale, S.; Amar, M.; Al-Khoury, S.; Dejeu, J.; Fadl, M.; Ronjat, M.; et al. Efficient functional neutralization of lethal peptide toxins in vivo by oligonucleotides. Sci. Rep. 2017, 7, 7202. [CrossRef]

171. Endean, R.; Rudkin, C. Studies of the venoms of some Conidae. Toxicon 1963, 1, 49-64. [CrossRef]

172. Kohn, A.J. Piscivorous Gastropods of the Genus Conus. Proc. Natl. Acad. Sci. USA 1956, 42, $168-171$. [CrossRef]

(C) 2020 by the authors. Licensee MDPI, Basel, Switzerland. This article is an open access article distributed under the terms and conditions of the Creative Commons Attribution (CC BY) license (http://creativecommons.org/licenses/by/4.0/). 